\title{
KOERI's Tsunami Warning System in the Eastern Mediterranean and Its Connected Seas: A Decade of Achievements and Challenges
}

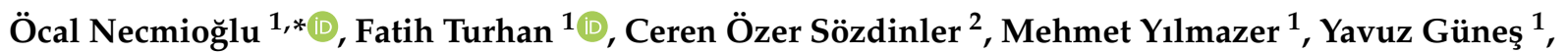

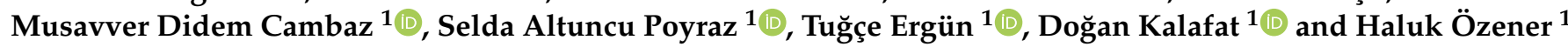 \\ 1 Kandilli Observatory and Earthquake Research Institute, Boğaziçi University, Istanbul 34684, Turkey; \\ fatih.turhan@boun.edu.tr (F.T.); mehmety@boun.edu.tr (M.Y.); gunesy@boun.edu.tr (Y.G.); \\ didem.samut@boun.edu.tr (M.D.C.); selda.altuncu@boun.edu.tr (S.A.P.); afacan@boun.edu.tr (T.E.); \\ kalafato@boun.edu.tr (D.K.); ozener@boun.edu.tr (H.Ö.) \\ 2 Department of Civil Engineering, Gebze Technical University Cayirova Campus, Gebze 41400, Turkey; \\ ceren.ozersozdinler@gtu.edu.tr \\ * Correspondence: ocal.necmioglu@boun.edu.tr
}

check for updates

Citation: Necmioğlu, Ö.; Turhan, F.; Özer Sözdinler, C.; Yılmazer, M.; Güneş, Y.; Cambaz, M.D.; Altuncu Poyraz, S.; Ergün, T.; Kalafat, D.; Özener, H. KOERI's Tsunami Warning System in the Eastern Mediterranean and Its Connected Seas: A Decade of Achievements and Challenges. Appl. Sci. 2021, 11, 11247. https://doi.org/10.3390/ app112311247

Academic Editor: Amadeo Benavent-Climent

Received: 31 October 2021

Accepted: 15 November 2021

Published: 26 November 2021

Publisher's Note: MDPI stays neutral with regard to jurisdictional claims in published maps and institutional affiliations.

Copyright: (c) 2021 by the authors. Licensee MDPI, Basel, Switzerland. This article is an open access article distributed under the terms and conditions of the Creative Commons Attribution (CC BY) license (https:// creativecommons.org/licenses/by/ $4.0 /)$.

\begin{abstract}
A tsunami warning system providing services in the Eastern Mediterranean, Aegean, Marmara and Black Seas under the UNESCO Intergovernmental Oceanographic Commission (IOC)Intergovernmental Coordination Group (ICG) for the Tsunami Early Warning and Mitigation System in the North-Eastern Atlantic, the Mediterranean and Connected Seas (NEAMTWS) framework was established in Turkey by the Kandilli Observatory and Earthquake Research Institute (KOERI) (Özel et al., 2011). KOERI's Regional Earthquake and Tsunami Monitoring Center (RETMC) was established on the foundations of the legacy KOERI National Earthquake Monitoring Center (NEMC) by adding observation, analysis and operational capability related to tsunami early warnings after an extensive preparatory period during 2009 and 2011. The center initiated its test-mode $7 / 24$ operational status as a national tsunami warning center in 2011, and after a one year period it became operational as a candidate tsunami warning center for NEAMTWS on 1 July 2012, together with CENALT (Centre d'Alerte aux Tsunamis-France) and followed by the NOA (National Observatory of Athens-Greece) on 28 August 2012, INGV (Instituto Nazionale di Geofisica e Vulcanologia-Italy) on 1 October 2014 and IPMA (Instituto Português do Mar e da Atmosfera-Portugal) on 1 February 2018, completing full coverage of the tsunami-prone regions monitored by NEAMTWS. In this paper, an overview of the progress and continuous improvement of KOERI's tsunami early warning system will be presented, together with lessons learned from important tsunamigenic events, such as the 20 July 2017 Bodrum-Kos Mw 6.6 and 30 October 2020 Samos-Izmir Mw 6.9 earthquakes. Gaps preventing the completion of an effective tsunami warning cycle and areas for future improvement are also addressed.
\end{abstract}

Keywords: tsunami warning; Eastern Mediterranean; KOERI; NEAMTWS

\section{Introduction}

The initial roadmap towards the establishment of a Tsunami Warning System in Turkey by the Kandilli Observatory and Earthquake Research Institute (KOERI), providing services in the Eastern Mediterranean, Aegean, Marmara and Black Seas under the UNESCO Intergovernmental Oceanographic Commission (IOC)—Intergovernmental Coordination Group (ICG) for the Tsunami Early Warning and Mitigation System in the North-Eastern Atlantic, the Mediterranean and Connected Seas (NEAMTWS) framework, was presented by [1]. A concise summary of the initiation and progress of the NEAMTWS upstream components and associated challenges was presented in [2,3]. KOERI's Regional Earthquake and Tsunami Monitoring Center (RETMC) was established after an extensive preparatory period between 2009 and 2011, by adding observation, analysis and operational capabilities related to early tsunami warnings to the foundations of KOERI's former 
National Earthquake Monitoring Center (NEMC). Its establishment relied on effective collaboration between various national stakeholders at that time, including the State Planning Organization (now Presidency of the Republic of Turkey-Strategy and Budget Presidency); General Directorate of Mapping (now General Directorate of Mapping); Office of Navigation, Hydrography and Oceanography; State Meteorological Service; Middle East Technical University; and General Directorate of Disaster Affairs-Earthquake Research Department (now AFAD-Earthquake Department). The center initiated its $7 / 24$ operational status as a national tsunami warning center in 2011, and after a one-year period it became operational as a candidate tsunami warning center for NEAMTWS on 1 July 2012, together with CENALT (France). This was followed by NOA (Greece) on 28 August 2012, INGV (Italy) on 1 October 2014 and IPMA (Portugal) on 1 February 2018, completing full coverage of the tsunami-prone regions of NEAMTWS. Since its establishment, KOERI has contributed significantly to the development of NEAMTWS by assuming various roles as a task team and working group co-chair or member. These have included roles related to architecture, operations, communication and tsunami exercises; hazard assessment and modeling; seismic and sea level monitoring; public awareness and preparedness; and maintenance of the NEAMTWS regional tsunami warning system, including the development of the NEAMTWS Tsunami Ready recognition program.

\section{NEAMTWS System Architecture}

The original operational concept for the NEAMTWS architecture was to establish, where possible, national tsunami warning centers in each country responsible for issuing warnings to the relevant authorities in the member states. In addition, some of the centers were envisaged to act as regional tsunami watch centers (RTWC) with responsibility for providing tsunami alerts in particular regions. Following further consideration of the developments made by other ICGs and recommendations by the IOC Working Group on Tsunamis and Other Hazards Related to Sea Level Warning and Mitigation Systems (TOWS-WG), encouraging standardization where appropriate, this concept evolved to include tsunami watch providers (TWP) and tsunami watch recipients (TWR). The concept of "watch providers" and "watch recipients" was later revised as "service providers" and "service recipients", respectively, by the IOC Working Group on Tsunamis and Other Hazards Related to Sea Level Warning and Mitigation Systems (TOWS) in 2014.

Tsunami Service Providers (TSP) are those NTWCs willing and able to provide tsunami alert information to other member states and their respective institutions at designated tsunami forecast points (TFP). Service recipients are Tsunami Warning Focal Points choosing to receive such information through subscription. A key aspect of this approach is that tsunami service providers do not have pre-determined geographical areas of responsibility. Each TSP is allowed to decide on its own service area as a function of its monitoring and analysis capabilities. NEAMTWS member states have the freedom to decide from which candidate tsunami service provider(s) they would like to receive tsunami messages, meaning that a Member State will be able to receive tsunami messages from more than one provider. As of submission of this manuscript, the list of subscribers to KOERI-TSP includes CDH (Cyprus), NIOF (Egypt), CENALT (France), BSH (Germany), DWD (Germany), NOA (Greece), PMO (Israel), INGV (Italy), NCGR (Lebanon), IPMA (Portugal), NIEP (Romania), TYPHOON (Russian Federation), DGPCE (Spain), IGN (Spain), CCS (United Kingdom), ERCC (EU) and the IOC Secretariat.

In order to be recognized as part of NEAMTWS, tsunami service providers must meet a number of requirements and be approved by the ICG of NEAMTWS. Until these conditions are met, they will be referred to as 'candidate' tsunami service providers. The relevant accreditation procedure was approved at the 9th session of ICG/NEAMTWS in 2012 in Southampton, UK. CENALT (France), INGV (Italy), KOERI (Turkey) and NOA (Greece) were accredited by ICG/NEAMTWS in 2016, followed by the accreditation of IPMA in 2019. 


\section{Monitoring and Service Area of the KOERI Tsunami Service Provider}

At the onset of its operations in 2012, the KOERI-TSP earthquake source monitoring area was bounded by $30^{\circ} \mathrm{N}$ to $48^{\circ} \mathrm{N}$ and $22^{\circ} \mathrm{E}$ to $44^{\circ} \mathrm{E}$. Based on the experience gained from the 25 October 2018 (UTC) Mw 6.8 Zakynthos (Ionian Sea) earthquake and subsequent minor tsunami, starting from 1 January 2019, KOERI updated its earthquake source monitoring area for TSP purposes as $30-48^{\circ} \mathrm{N}$ and $19-44^{\circ} \mathrm{E}$, excluding the Gulf of Corinth. KOERI monitors the earthquake activity in the earthquake source monitoring area, evaluates its tsunamigenic potential and sends tsunami messages to the subscribers for earthquakes of magnitudes larger than 5.5, according to the decision matrix in operational use. Messages include a set of tsunami forecast points (TFP), locations where the tsunami service provider, or another organization, provides an estimate of the tsunami arrival time, alert level or wave height. TFPs (Figure 1) may correspond to important coastal cities or populations or to the locations of sea level gauges [4]. For the selection of TFPs in Turkey, locations of ports, shipyards, marinas, oil refineries, coastal airports, touristic destinations, densely populated beaches and existing tide gauge stations have been considered based on the following criteria: (1) at least one point for each administrative division has been selected; (2) priority is given to the existing mareograph stations, and no limits are applied to the number of mareograph stations per administrative division. TFPs officially communicated to the IOC by NEAMTWS member states are included in KOERI-RETMC's messages. For those NEAMTWS member states where no TFPs have been officially communicated to IOC, KOERI has selected TFPs to ensure that no NEAMTWS Member State coastal zone is excluded from its services.

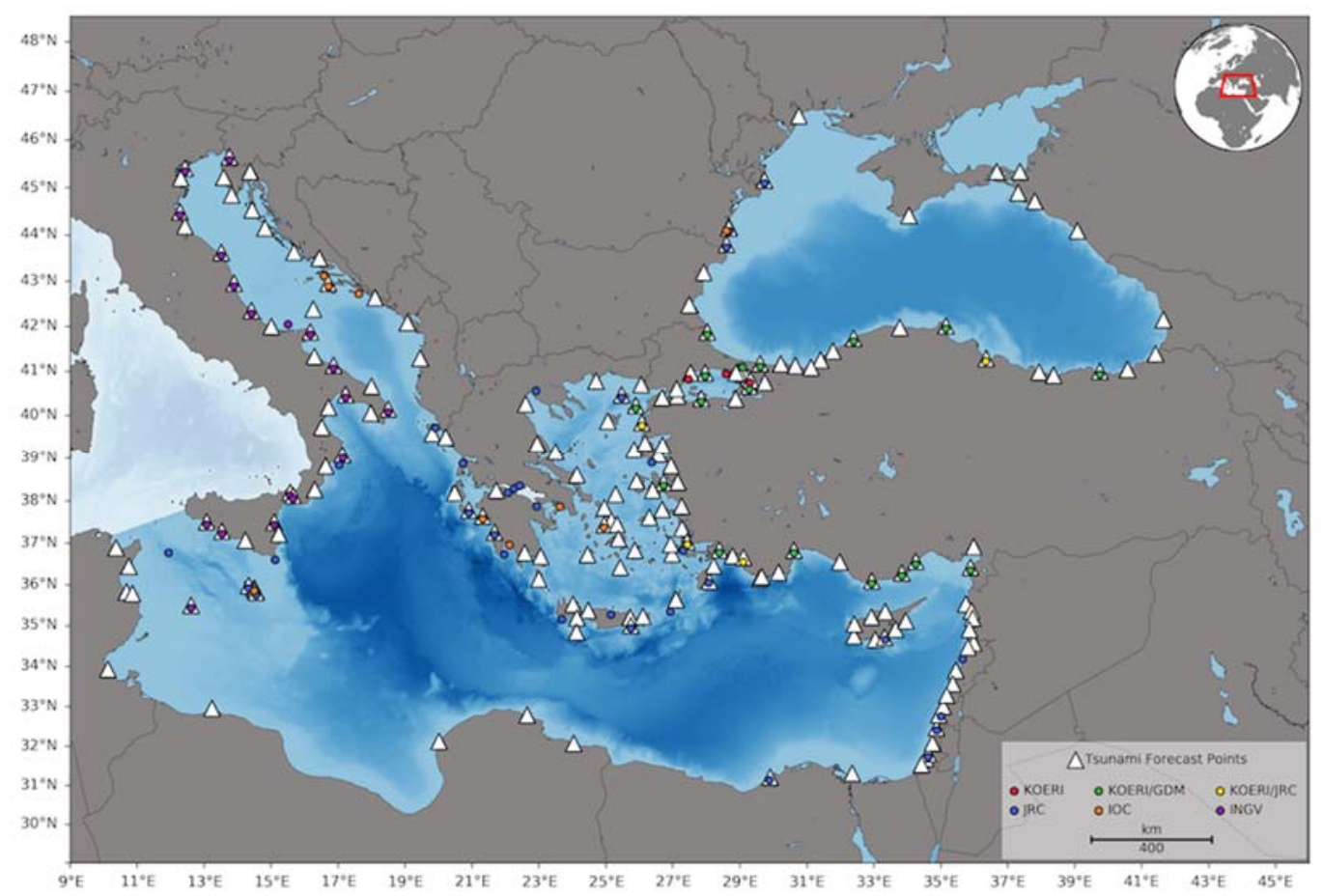

Figure 1. KOERI-TSP service area (which excludes the Western Mediterranean and Corinth Gulf), tsunami forecast points (TFPs—-shown as white triangles) included in its messages and tide gauges (shown as colored dots) available to KOERI-RETMC in its TSP operations.

\section{Seismic Monitoring}

Earthquake observation at KOERI dates back to the 1894 Istanbul earthquake. Seismic monitoring facilities have continued for more than a century since the installation of the first seismometer in 1895. Details of KOERI earthquake catalogues [5,6] and seismic network evolutions $[6,7]$ have been presented in earlier studies. In order to obtain reliable 
earthquake parameters, today REMTC operates a seismic network including 256 sensors that comprise broadband (BB), accelerometer (SM) and short-period (SP) seismometers. Sensor numbers exceed 350 when including other national and international institutes operating and distributing data around the Mediterranean Region (e.g., AC: Albanian Seismological Network (AC); BS: National Seismic Network of Bulgaria (BS); GE: GEOFON; GO: National Seismic Network of Georgia; HL: National Observatory of Athens Seismic Network; HT: Aristotle University of Thessaloniki Seismological Network; HU: Hungarian National Seismological Network (HSN); II: Global Seismograph Network-IRIS/IDA (GSN); IMS: International Monitoring System (CTBTO-IMS); IS: Israel National Seismic Network; IU: Global Seismograph Network-IRIS/USGS (GSN); IV: Italian National Seismic Network (INSN); MN: Mediterranean Very Broadband Seismographic Network (MedNet); OE: Austrian Seismic Network; OX: North-East Italy Seismic Network; RO: Romanian Seismic Network (NIEP); TU: Turkish National Seismic Network (TNSN)). The average data availability performance of the KOERI seismic network is around $80 \%$ annually.

The earthquake detection threshold of the KOERI seismic network was studied over different time periods using the KOERI earthquake catalogue. Magnitude of completeness (Mc) values ranging between 2.6 and 2.9 [8] were obtained by using the earthquake catalogues for the period 1975-2015. As a result of the increased sensor number, an Mc value of around 2.0 was computed [5] with the use of the earthquake catalogue for the period 2013-2017. In order to present the detection capability in the tsunami service provider monitoring area, seismic network distribution and noise levels were used as described in the SN-CAST software [9]. According to the use of seismic station coordinates and noise levels in the KOERI network, the geographical distributions of the minimum detectable magnitude (Ml) in Turkey and surrounding regions were computed (Figure 2). The results showed that the minimum detectable threshold mainly changes between 1.0 and 2.0 inside the landmass of Turkey and in the range of 2.0 to 4.0 in most of the neighborhood areas outside the country. This provides sufficient detection magnitude for possible tsunami warnings, not only inside the country's borders but also inside the whole tsunami service provider monitoring area.

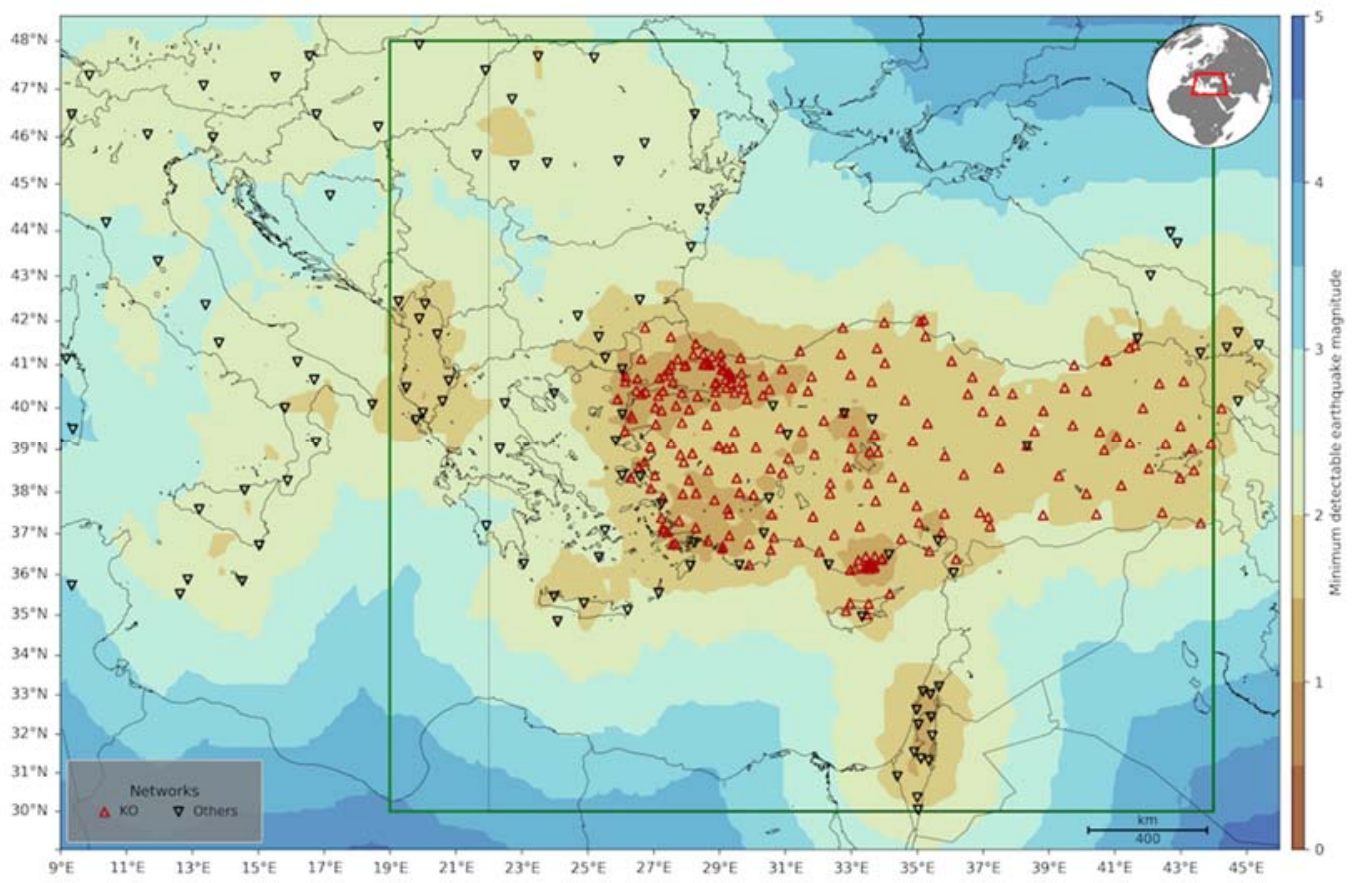

Figure 2. Regional seismic stations available to KOERI-RETMC within its TSP operations area and regional earthquake magnitude threshold map of KOERI-TSP. Red upwards pointing triangles show KOERI's own seismic stations, whereas black downwards pointing arrows show stations available from other networks. The earthquake monitoring area (dotted line until 2019) is shown with green rectangles. 


\section{Automatic Determination of Earthquake Parameters: SeisComP3 and Early-Est}

SeisComP $[10,11]$ and Early-est [12-16] are the main pillars of KOERI's automatic seismic monitoring system. The development of SeisComp3 for event detection and location was driven by the GITEWS project in the aftermath of the catastrophic 2004 Sumatra tsunami, focusing on the optimization of the ability to monitor and rapidly characterize potentially tsunamigenic earthquakes at both regional and global scales [10]. SeisComP has been one of the main operational tools used by KOERI-RETMC since 2009. SeisComP3 is configured for local, regional and global seismic monitoring and automatically computes $\mathrm{ML}, \mathrm{mb}, \mathrm{mB}, \mathrm{Mw}(\mathrm{mB}), \mathrm{Mwp}, \mathrm{Mw}(\mathrm{Mwp})$ and $\mathrm{M}$ magnitudes according to earthquake size. Together with Early-est [12-16], it constitutes the backbone of the present 7/24 operational tsunami warning system. Early-est software has been used at KOERI-RETMC since 2016, as the preferred routine operational analysis tool for rapid detection, location and seismic or tsunamigenic characterization of earthquakes within the service area. Early-est automatically computes mb, Mwp and Mwpd magnitudes. The KOERI configuration of Early-Est primarily focuses on regional and global earthquake monitoring using approximately 550 stations from 78 networks.

\section{Sea Level Monitoring}

At the national level, 18 out of 20 tide gauge stations operated by the General Directorate of Mapping (GDM) are integrated into the operations of KOERI-TSP. The integration of the entire GDM network to KOERI-RETMC is dependent on GDM's plans to upgrade the whole network with radar-type tide gauges, which is expected be finalized by 2022 . Four Inexpensive Device or Sea Level (IDSL) stations [17] donated by EC-JRC have been installed in Bodrum, Bozcaada and Fethiye in the Aegean Sea and in Samsun in the Eastern Black Sea. Recent efforts focused on the installation of multihazard monitoring systems along the Marmara Coast, composed of accelerometer, tide gauge and meteorological sensors, which will be expanded by the observation capability of GNSS in the future. Three systems out of a proposed network consisting of 50 systems have already been installed along the northern coasts of the Marmara Sea. Sea level data are available to other TSPs and the IOC through an http protocol. Sea level data from INGV-TSP are available through a bilateral agreement and data from various providers are accessible through the IOC Sea Level Monitoring Facility [18] and JRC TAD Server [19]. All tide gauges available to KOERI-RETMC in its TSP operations are presented in Figure 1.

\section{KOERI-TSP Decision Support System}

The KOERI-TSP system relies on the fast and reliable determination of the location, magnitude and depth of an earthquake to assess its tsunamigenic potential through a decision matrix (Figure 3). KOERI-TSP disseminates tsunami messages to its subscribers based on the alert level and guided by this decision matrix. The target time of the dissemination of the first message is set as $7 \mathrm{~min}$ after the earthquake origin time because of the seismologically unavoidable trade-off between accuracy and the timely availability of the earthquake magnitude information to the duty officer on shift.

KOERI-TSP's decision support system was initially based on the NEAMTWS Operational Concept Decision Matrix presented in [4]. Nevertheless, KOERI modified this initial decision matrix over time based on supporting scientific studies, such as [20,21], and its operational experience-so-called "best practices". The current decision matrix in operation (Figure 3) is less conservative in comparison to the NEAMTWS Decision Matrix for the Mediterranean in terms of Mw thresholds, although associates the 'information' alert level with "low tsunami potential" on the grounds of the possibility of a triggered submarine landslide. Basin-wide 'watch' (highest alert level) messages are issued only for events with $\mathrm{Mw} \geq 7.5$. The decision support matrix, which translates alert levels into anticipated wave amplitude and run-up values, is implemented in accordance with [4]. 


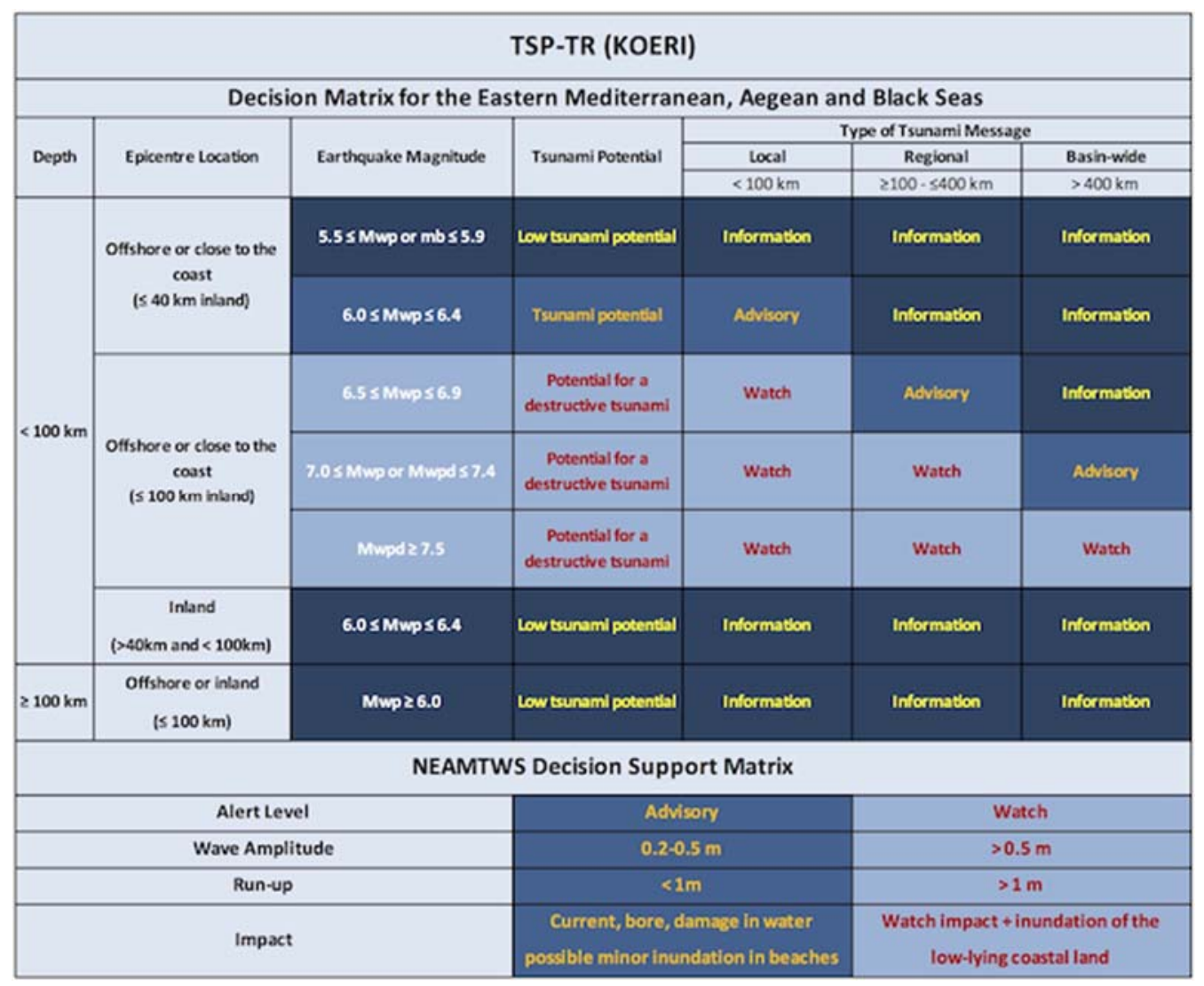

Figure 3. KOERI-RETMC decision matrix (top) and NEAMTWS decision support matrix used in KOERI-TSP operations.

The message content conforms to the various message types defined by [4]. A slight modification indicating the possibility of a tsunami being caused by a submarine landslide generated by an earthquake was introduced in the 'information' message in 2015. In 2018, a statement was added to the initial message addressing the magnitude uncertainty by stating that the magnitude as the basis of the initial bulletin may be subject to further revision upon availability of additional seismic data, which may differ from the final magnitude estimation. The messages clearly indicate that the alerts apply to countries subscribed to the services of KOERI-TSP and within its monitoring area, and all prescribed parameters are contained in the message. For tsunamigenic events, the duty officer (staff responsible for sending the tsunami alert messages according to the decision matrix) on shift starts monitoring the tsunami propagation after the dissemination of the first message via real-time sea level data transmitted from tide gauge stations to KOERI servers. In the meantime, if the earthquake magnitude has been revised in such a way that the alert level in the initial message needs to be raised, a second message with the revised earthquake magnitude should be sent within $15 \mathrm{~min}$ of the earthquake origin time. If a tsunami is observed at any tide gauge station in the event area, an 'ongoing' message is prepared by the duty officer, including the measured sea level data, such as the name and coordinates of tide gauge station, the arrival time of the first wave, the maximum wave amplitude and the period of the observed wave. As stated in [4], the watch level indicates the potential for a tsunami along the coast with a wave height higher than $0.5 \mathrm{~m}$, while the advisory level corresponds to wave heights between $0.2 \mathrm{~m}$ and $0.5 \mathrm{~m}$. However, the tsunami watch alert level is not downgraded to the advisory level by KOERI-TSP if the measured sea level at the tide gauge station is less than $0.5 \mathrm{~m}$, simply because of the fact that the sea level measured at the second closest tide gauge station may very well exceed $0.5 \mathrm{~m}$, especially considering the limited availability of coastal tide gauge stations. The duty officer proceeds to monitor tsunami propagation and whether tsunami waves are observed at any other station or set of stations, then the next ongoing message is disseminated. The process of 
monitoring the evolution of a tsunami is assisted through a pre-calculated tsunami scenario database composed of 2415 scenarios in the service area [20,21]. If there are no more tsunami observations at the stations, the 'end' message can be disseminated at that stage, upon consultation with AFAD, the national civil protection authority of Turkey. At that stage, KOERI-TSP must ensure an adequate number of tide gauge stations is monitored and that the tsunami event has ended at the basin. In recent years, an informal information channel between KOERI and NOA was also established to promote enhanced collaboration and a culture of interoperability among TSPs providing services in the same basin. If no tsunami is confirmed at any tide gauge, then a 'cancellation' message is disseminated. The corresponding flow chart and simplified standard operational procedure are provided in Figure 4 and Table 1, respectively.

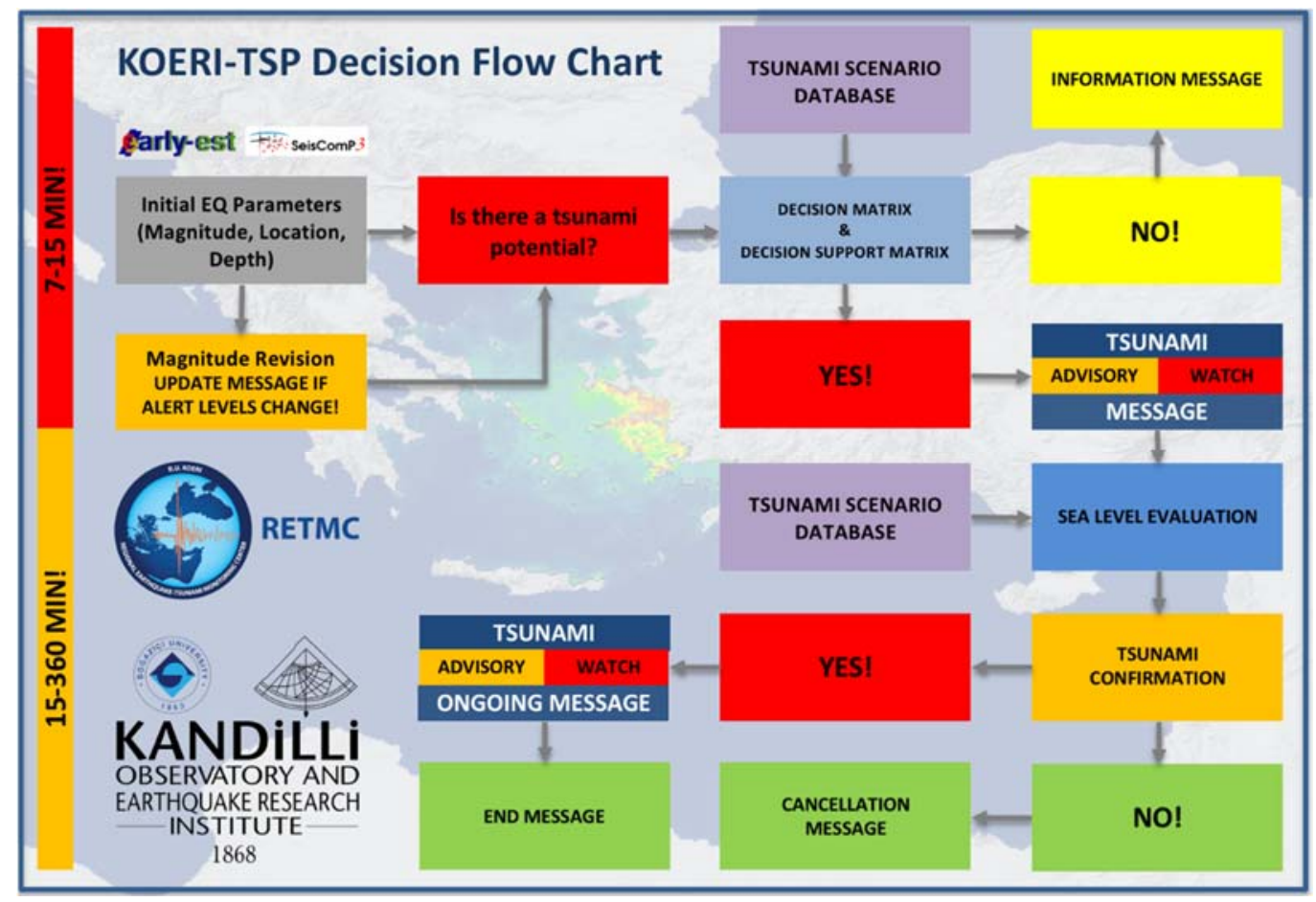

Figure 4. Decision flow-chart for KOERI-TSP.

Table 1. Simplified SOP for the KOERI-TSP duty officer.

\begin{tabular}{|c|c|}
\hline $\begin{array}{c}\text { Mwp } \geq 6.0 \\
\text { LOCATION OFFSHORE or } \leq 100 \mathrm{KM} \text { INLAND } \\
\text { DEPTH } \geq 100 \mathrm{KM}\end{array}$ & $\begin{array}{l}\text { ISSUE INFORMATION FOR LOCAL, REGIONAL AND BASIN-WIDE TFPs. } \\
\text { MONITOR SEA LEVEL STATIONS AT ALL DISTANCES FOR } 60 \text { MIN AND VERIFY } \\
\text { WHETHER TSUNAMI IS GENERATED OR NOT. }\end{array}$ \\
\hline $\begin{array}{c}5.5 \leq \mathrm{mb} \text { or Mwp } \leq 5.9 \\
\text { LOCATION OFFSHORE or } \leq 40 \mathrm{KM} \text { INLAND } \\
\text { DEPTH }<100 \mathrm{KM}\end{array}$ & $\begin{array}{c}\text { ISSUE INFORMATION FOR LOCAL, REGIONAL AND BASIN-WIDE TFPs. } \\
\text { MONITOR SEA LEVEL STATIONS AT ALL DISTANCES FOR } 60 \text { MIN AND VERIFY } \\
\text { WHETHER TSUNAMI IS GENERATED OR NOT. }\end{array}$ \\
\hline $\begin{array}{c}6.0 \leq \mathrm{Mwp} \leq 6.4 \\
\text { LOCATION } 40-100 \text { INLAND } \\
\text { DEPTH }<100 \text { KM }\end{array}$ & $\begin{array}{c}\text { ISSUE INFORMATION FOR LOCAL, REGIONAL AND BASIN-WIDE TFPs. } \\
\text { MONITOR SEA LEVEL STATIONS AT ALL DISTANCES FOR } 60 \text { MIN AND VERIFY } \\
\text { WHETHER TSUNAMI IS GENERATED OR NOT. }\end{array}$ \\
\hline $\begin{array}{c}6.0 \leq \mathrm{Mwp} \leq 6.4 \\
\text { LOCATION OFFSHORE or } \leq 40 \mathrm{KM} \text { INLAND } \\
\text { DEPTH }<100 \mathrm{KM}\end{array}$ & $\begin{array}{l}\text { ISSUE ADVISORY FOR LOCAL AND INFORMATION FOR REGIONAL AND } \\
\text { BASIN-WIDE TFPs. MONITOR SEA LEVEL STATIONS AT ALL DISTANCES FOR } 120 \\
\text { MIN AND VERIFY WHETHER TSUNAMI IS GENERATED OR NOT. }\end{array}$ \\
\hline $\begin{array}{c}6.5 \leq \mathrm{Mw} \leq 6.9 \\
\text { LOCATION } \leq 100 \mathrm{KM} \text { INLAND } \\
\text { DEPTH }<100 \mathrm{KM}\end{array}$ & $\begin{array}{l}\text { ISSUE WATCH FOR LOCAL, ADVISORY FOR REGIONAL AND INFORMATION } \\
\text { FOR BASIN-WIDE TFPs. MONITOR SEA LEVEL STATIONS AT ALL DISTANCES FOR } \\
180 \text { MIN AND VERIFY WHETHER TSUNAMI IS GENERATED OR NOT. }\end{array}$ \\
\hline $\begin{array}{c}7.0 \leq \mathrm{Mw} \leq 7.4 \\
\text { LOCATION } \leq 100 \mathrm{KM} \text { INLAND } \\
\text { DEPTH }<100 \mathrm{KM}\end{array}$ & $\begin{array}{l}\text { ISSUE WATCH FOR LOCAL AND REGIONAL AND ADVISORY FOR BASIN-WIDE } \\
\text { TFPs. MONITOR SEA LEVEL STATIONS AT ALL DISTANCES FOR } 240 \text { MIN AND VERIFY } \\
\text { WHETHER TSUNAMI IS GENERATED OR NOT. }\end{array}$ \\
\hline
\end{tabular}


Table 1. Cont.

\begin{tabular}{|c|c|}
\hline $\begin{array}{l}\text { Mw } \geq 7.5 \\
\text { LOCATION } \leq 100 \mathrm{KM} \text { INLAND } \\
\text { DEPTH }<100 \mathrm{KM}\end{array}$ & $\begin{array}{l}\text { ISSUE WATCH FOR LOCAL, REGIONAL AND BASIN-WIDE TFPs. MONITOR SEA } \\
\text { LEVEL STATIONS AT ALL DISTANCES FOR } 360 \text { MIN AND VERIFY WHETHER } \\
\text { TSUNAMI IS GENERATED OR NOT. }\end{array}$ \\
\hline MAGNITUDE REVISIONS & $\begin{array}{l}\text { IF THE MAGNITUDE IS REVISED, WHICH REQUIRES A NEW MESSAGE WITH A } \\
\text { DIFFERENT ALERT LEVEL ISSUE A NEW MESSAGE AFTER } 15 \text { MIN OF } \\
\text { EARTHQUAKE ORIGIN TIME BASED ON THIS REVISED MAGNITUDE. UPDATE } \\
\text { MESSAGE NUMBER MANUALLY AS 002. FOR EXAMPLE, IF THE INITIAL } \\
\text { MAGNITUDE IS } 6.5 \leq \mathrm{Mw}<7.0 \text { AND THE REVISED MAGNITUDE IS STILL } 6.5 \leq \mathrm{Mw}< \\
\text { 7.0, DO NOT ISSUE A NEW MESSAGE BASED ON MAGNITUDE REVISION. HOWEVER, } \\
\text { IF THE INITIAL MAGNITUDE IS } 6.5 \leq \mathrm{Mw}<7.0 \text { AND THE REVISED MAGNITUDE IS } \\
\text { Mw } 7.0 \geq \text { OR } 6.0 \leq \mathrm{Mw}<6.5, \text { THEN ISSUE A NEW MESSAGE WITH THE UPDATED } \\
\text { ALERT LEVELS. }\end{array}$ \\
\hline SEA-LEVEL OBSERVATIONS & $\begin{array}{l}\text { MONITOR SEA-LEVEL STATIONS FOR ALL CASES AS DESCRIBED ABOVE. } \\
\text { IF THE SEA LEVEL OBSERVATION CONFIRMS THE TSUNAMI AND VERIFIES THE } \\
\text { ALERT LEVEL DETERMINED BY THE INITIAL MESSAGE (FOR EXAMPLE, IF THE } \\
\text { ALERT LEVEL IS ADVISORY FOR THE TFP AND THE MEASURED WAVE HEIGHT IS } \\
\text { BETWEEN 0.2M AND 0.5M OR IF THE ALERT LEVEL IS WATCH FOR THE TFP AND THE } \\
\text { MEASURED WAVE HEIGHT IS HIGHER THAN 0.5M) THEN ISSUE AN ONGOING } \\
\text { MESSAGE KEEPING THE SAME ALERT LEVELS DEFINED IN THE INITIAL } \\
\text { MESSAGE. IF AT A LATER STAGE A HIGHER WAVE HEIGHT IS OBSERVED AT } \\
\text { THE SEA LEVEL STATION EVEN IT DOES NOT CORRESPOND TO A HIGHER } \\
\text { ALERT LEVEL, THEN ISSUE AN ONGOING MESSAGE WITH THE UPDATED } \\
\text { OBSERVATION. } \\
\text { IF THE SEA LEVEL OBSERVATION CONFIRMS THE TSUNAMI BUT THE } \\
\text { OBSERVED WAVE HEIGHT CORRESPONDS TO A HIGHER LEVEL OF ALERT (FOR } \\
\text { EXAMPLE, IF THE ALERT LEVEL IS ADVISORY FOR THE TFP AND THE MEASURED } \\
\text { WAVE HEIGHT IS HIGHER THAN 0.5M), THEN ISSUE AN ONGOING MESSAGE } \\
\text { WITH UPDATED ALERT LEVEL. } \\
\text { IF THE SEA LEVEL OBSERVATION CONFIRMS THE TSUNAMI BUT THE } \\
\text { OBSERVED WAVE HEIGHT CORRESPONDS TO A LOWER LEVEL OF ALERT (FOR } \\
\text { EXAMPLE, IF THE ALERT LEVEL IS WATCH FOR THE TFP AND THE MEASURED WAVE } \\
\text { HEIGHT IS BETWEEN 0.2M AND 0.5M OR IF THE ALERT LEVEL IS ADVISORY FOR THE } \\
\text { TFP AND THE MEASURED WAVE HEIGHT IS LESS THAN 0.2M), THEN ISSUE AN } \\
\text { ONGOING MESSAGE KEEPING THE SAME ALERT LEVELS DEFINED IN THE } \\
\text { INITIAL MESSAGE. }\end{array}$ \\
\hline CANCELATION MESSAGE & $\begin{array}{l}\text { IF A WATCH AND/OR ADVISORY MESSAGE HAS BEEN ISSUED AND TSUNAMI IS } \\
\text { NOT VERIFIED WITHIN THE CORRESPONDING TIME FRAME GIVEN ABOVE, } \\
\text { THEN ISSUE A CANCELLATION MESSAGE. }\end{array}$ \\
\hline END MESSAGE & $\begin{array}{l}\text { IF A WATCH AND/OR ADVISORY MESSAGE HAS BEEN ISSUED AND TSUNAMI IS } \\
\text { VERIFIED AND OBSERVED, THEN ISSUE AN END MESSAGE IN CONSULTATION } \\
\text { WITH THE CIVIL PROTECTION AGENCY. }\end{array}$ \\
\hline
\end{tabular}

\section{Operational Tools-From EC-JRC to TsuComp with Enhanced Products}

At the onset of its operationalization, KOERI-RETMC's tsunami warning system relied on EC-JRC's Tsunami Analysis Tool (TAT) thanks to a collaborative agreement between EC-JRC and KOERI, which also included the availability of EC-JRC's MOD1 and MOD2 Tsunami Scenario Databases to support KOERI-RETMC's operations. All KOERI duty officers have received regular and comprehensive training on the use of TAT. The steady evolution of the operational system required the development of an in-house tool eliminating external assistance and support. TsuComp (Tsunami Message Composer Tool) was the outcome of this process and has been KOERI's main operational tool since 1 January 2018, which was developed by KOERI-RETMC within the FP7 ASTARTE framework (Assessment, Strategy and Risk Reduction for Tsunamis in Europe-FP7-ENV2013 6.4-3, Grant 603839) as a basic operational interface for tsunami analysis, message generation and dissemination (Figure 5). TsuComp is designed to process a given set of earthquake parameters and sea level data to generate corresponding messages under user control and to disseminate these via selected communication channels, such as e-mail, fax, GTS and SMS, in both Turkish and English simultaneously. If needed, additional language functionalities can also be added. In addition, each message generated by the system can be manually modified by the duty officer. Although the decision matrix is the primary source for creating messages, TsuComp is also capable of disseminating tsunami messages through tsunami 
scenario databases, including MOD2-TR [20,21]. One of the main strengths of TsuComp is its capability to disseminate enhanced products produced with Generic Mapping Tools (GMT; [22]), namely Travel Time using the Tsunami Travel Time (TTT) software provided by the UNESCO/IOC-NOAA International Tsunami Information Center, as well as the tsunami forecast point alert level and distance-based tsunami alert maps, as attachments to the e-mail message. TsuComp was successfully demonstrated at the 6th JRC ECML Crisis Management Technology Workshop on Tsunami Decision Support Systems (TDSS-2015) held in the European Crisis Management Laboratory (ECML) of the Joint Research Center in Ispra, Italy, from 2-3 July 2015 [23].

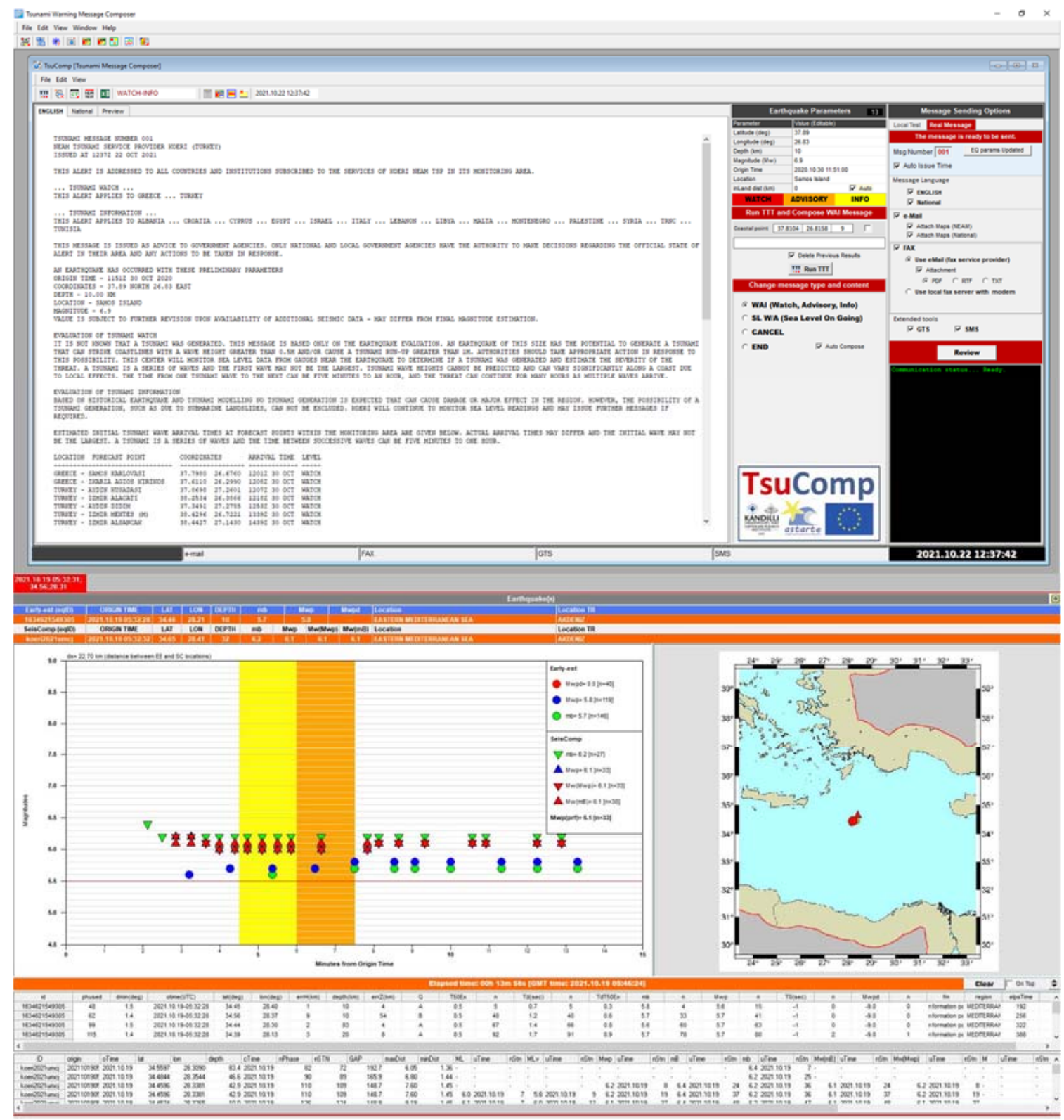

Figure 5. Main interface of TsuComp (top) and one of its sub-windows showing the various types of earthquake magnitudes calculated in real-time through automatic systems SeisComP3 and Early-est (bottom), where the duty officer is able to initiate the generation of the tsunami alert message by just clicking on the respective earthquake magnitude symbol.

Since the establishment of ICG/NEAMTWS, steady criticism was provided by the Civil Protection Authorities (CPA) concerning the difficult structure of the text-only tsunami bulletins. The first tsunami exercise of NEAMTWS, NEAMWave12, was a good 
opportunity to explore the possibility of making use of enhanced products as attachments to the e-mail messages. During NEAMWave12, messages with enhanced products were disseminated at the national level to the AFAD (Turkish CPA) according to the master schedule of events list (MSEL) of the exercise. These enhanced products were produced by the EU-FP7 TRIDEC project [24]. During NEAMWave14, in addition to the NEAMTWS messages, KOERI disseminated enhanced products via its TsuMessenger (prototype version of TsuComp) developed within the EU-FP7 Project ASTARTE, such as the distance-based tsunami alert map, tsunami forecast point alert level map and tsunami travel map products in the first message to the Turkish CPA (AFAD). It should be noted that prior to NEAMWave14, on 1 October 2014, the US NOAA Pacific Tsunami Warning Center (PTWC) commenced issuance of new Enhanced Tsunami Products for all Pacific countries, culminating a 7-year intergovernmental process coordinated by the IOC through its Intergovernmental Coordination Group for the Pacific Tsunami Warning and Mitigation System (ICG/PTWS). As a result of this significant progress, the 12th session of the ICG/NEAMTWS in 2015 recommended that NTWCs, in consultation with their CPAs, evaluate the need to provide enhanced products in the NTWC messages, such as maps, and to present and make proposals for discussion and adoption at its next session. No decision was taken at the 13th session of ICG/NEAMTWS in 2016, although the NEAMTWS Working Group on Public Awareness, Preparedness and Mitigation (WG4) recommended keeping the requirement for enhanced TSP products, even if its implementation is not foreseen in the short term. In NEAMWave17, national messages with enhanced products were sent to the Turkish CPA (AFAD) using KOERI's TsuComp (formerly TsuMessenger) software developed within the framework of EC/FP-7 Project ASTARTE. NEAMWave17 was the final full-scale testing of TsuComp prior to its operationalization by KOERI as of 1 January 2018. At its 14th session in 2017, ICG/NEAMTWS WG4 recommended analysis of and improvements to the NEAMTWS national tsunami messages. In the meantime, KOERI's intention to disseminate enhanced products to its subscribers in 2018 for a period of one year for the purpose of testing and evaluation was noted. So far, KOERI still remains the only NEAMTWS TSP disseminating such products to its subscribers. Examples of these products are given in Figures 6 and 7.

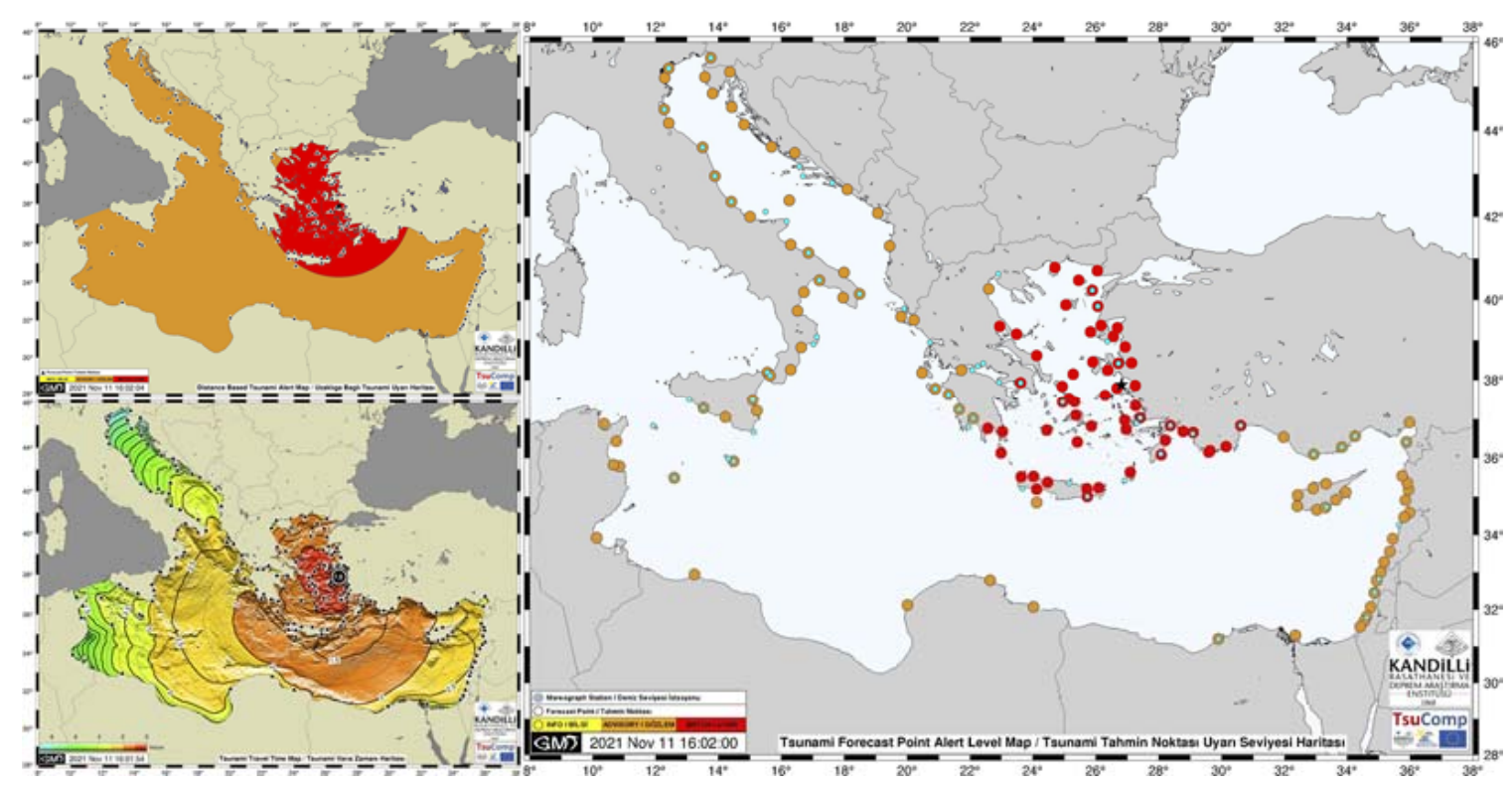

Figure 6. Distance-based tsunami alert map (top left), tsunami travel time map (bottom left) and tsunami forecast point alert level map (right) disseminated to KOERI-TSP subscribers for the 30 October 2020 Samos earthquake based on the Mw 7.0 assessment used in the initial warning message. 


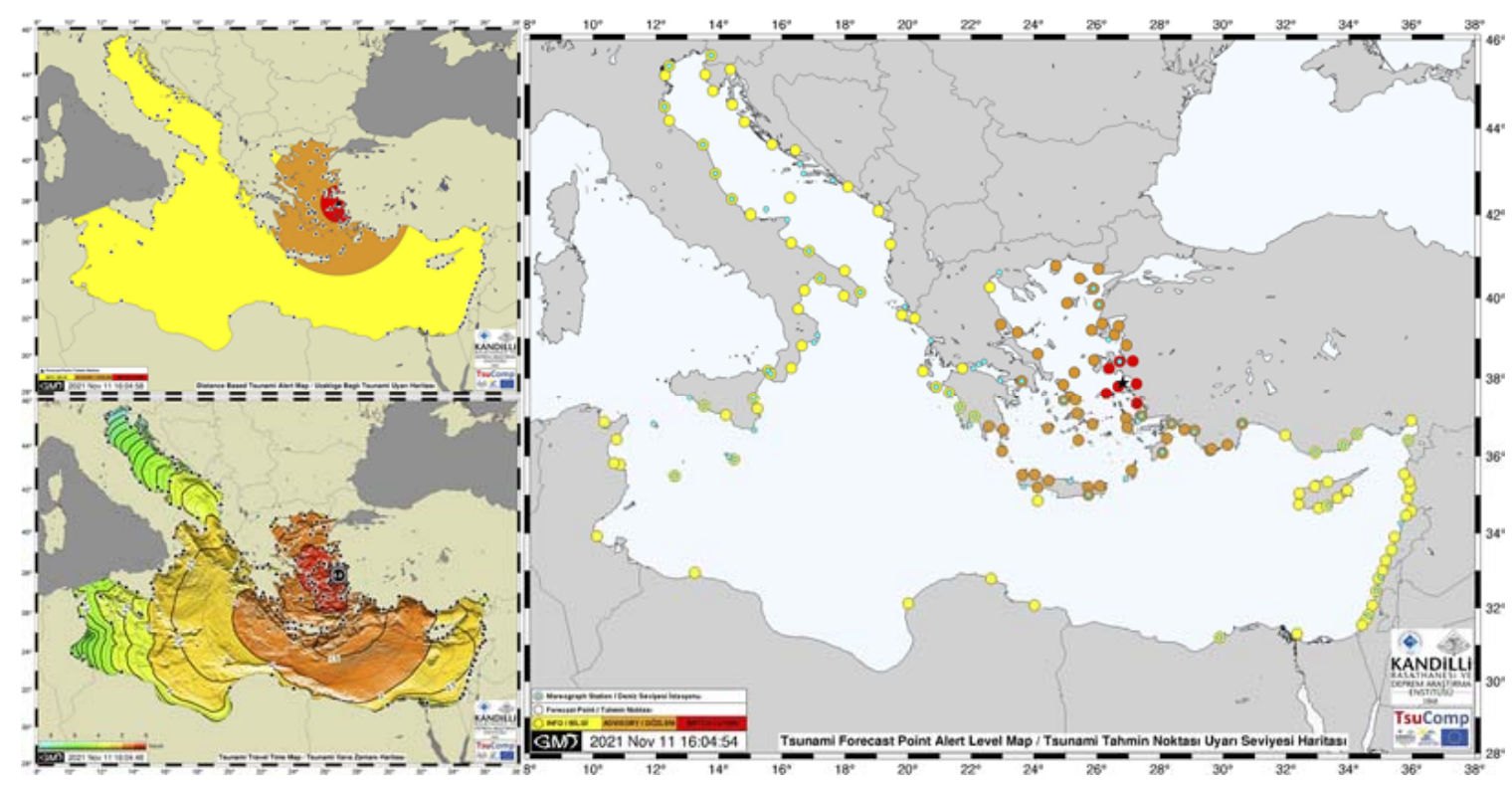

Figure 7. Distance-based tsunami alert map (top left), tsunami travel time map (bottom left) and tsunami forecast point alert level map (right) corresponding to 30 October 2020 Samos earthquake based on Mw 6.9 as the final magnitude calculated for this earthquake by KOERI.

\section{Communication Channels}

E-mail messages are disseminated through an in-house e-mail platform using a general SMTP server. The Interfax system (http:/ / www.interfax.net/en, accessed on 17 November 2021) is used for fax message dissemination, enabling fax messages to be sent to multiple recipients simultaneously. National and international SMS dissemination is available through an external service provider. International SMS dissemination was utilized for the first time during NeamWave21 and is now a regular component of KOERI-RETMC's operational service. In cooperation with the Turkish State Meteorological Service (TSMS), KOERI has its own GTS system and is connected to GTS via its own satellite hub. All communication channels are subject to testing during monthly communication test exercises. Efforts are in place to enable message dissemination through Common Alerting Protocol (CAP).

\section{Getting Ready for the Real Event}

Tsunami service providers (TSP), national tsunami warning centers (NTWC) and tsunami warning focal points (TWFP) must maintain a high level of readiness to be able to act efficiently and effectively to provide warnings to their subscribers during fast-onset and rapidly evolving natural disasters such as tsunamis. To maintain this high state of operational readiness, and especially for infrequent events such as tsunamis, TSPs and emergency agencies must regularly practice their response procedures to ensure that vital communication links work seamlessly and that agencies and response personnel know the roles that they will need to play during an actual event. Internal exercises, communication tests and tsunami exercises play vital roles in addressing these fundamental requirements [25].

\subsection{Internal Tsunami Exercises}

KOERI-RETMC duty officers perform internal exercises for the tsunami warning system on each shift (three times a day) based on a pre-determined set of scenarios, which ensures operational readiness for possible tsunamis as infrequent events. Exercise scenarios are designed considering the locations of historical tsunamigenic earthquakes but with a range of magnitudes corresponding to all alert levels. An internal group of experts evaluates these exercises and provides feedback to the duty officers on a monthly basis. The $97 \%$ average success rate of these exercises clearly demonstrates the need for practice. 


\subsection{Communication Test Exercises}

Initial communication test exercises were planned, conducted and evaluated by the ICG/NEAMTWS Task Team on Communication Test Exercises (TT-CTE) in June and September 2010. The communication links used were limited to e-mail and fax at that time. Despite the small scale and limitations, these two first communication test exercises provided the required capacity-building that opened the way to the first enlarged communication test in 2011, where KOERI was the message provider, which was followed by further tests until 2015. The scope of these tests was limited to the candidate tsunami service providers at that time (NOA, CENALT, IPMA and KOERI) in order to perform a thorough evaluation of the procedures for broadcasting and receiving tsunami messages. Starting in 2016, each candidate TSP now organizes monthly communication tests with their subscribers. There is a dedicated team of experts at KOERI responsible for planning, conducting, responding and evaluating these exercises.

\subsection{NEAMTWS Tsunami Exercises \\ 10.3.1. NEAMWave12}

KOERI participated in NEAMWave12 [25], the first tsunami exercise in the NEAM region, as a candidate tsunami service provider for a scenario based on a $\mathrm{Mw}=8.4$ worst-case interpretation of the 8 August 1303 Crete and Dodecanese Islands earthquake, resulting in destructive inundation in the Eastern Mediterranean. Here, 12 messages were disseminated within a $3 \mathrm{~h}$ timeframe to the relevant end-users, whereby four dedicated messages were sent to the NEAMTWS member states via e-mail, fax and GTS, targeting the subscribers of the KOERI scenario in terms of affected areas. Besides the NEAMTWS messages, KOERI also sent messages in Turkish language to the Disaster and Emergency Management Presidency of Turkey (AFAD). AFAD and other selected internal end-users were also provided with the messages produced by the TRIDEC Natural Crisis Management System, developed within the same EC-FP7 Project, where end-users were also provided with various maps. In addition, KOERI also monitored the IPMA scenario through the unique system-to-system communication capabilities of TRIDEC [24]. The final evaluation of the exercise indicated that the messages were disseminated successfully and both KOERI and AFAD benefited from the exercise considerably, representing the first time the NEAMTWS Tsunami Warning Chain System was tested to full scale.

\subsubsection{NEAMWave14}

NEAMWave14 [26], as the second NEAM tsunami exercise, was held on 28-30 October 2014. NEAMWave14 involved the simulation of the assessment of a tsunami based on an earthquake-driven scenario followed by alert message dissemination by candidate tsunami service providers (CTSP; phase A) and continued with the simulation of the actions of the tsunami warning focal points (TWFP), national tsunami warning centers (NTWC) and Civil Protection Authorities (CPA) (phase B) as soon as the message produced in phase A was received. Differing from the tsunami exercise in 2012, NEAMWave14 also included phase C, which simulated the activation of the European Union Civil Protection Mechanism at the international level as soon as the message produced in phase A was received by the European Commission Emergency Response and Coordination Center (ERCC). In NEAMWave14, KOERI acted as the message provider for a Black Sea scenario, where Black Sea was covered for the first time in a NEAMTWS tsunami exercise.

\subsubsection{NEAMWave17}

KOERI-RETMC participated in NEAMWave17 [27] in a scenario based on an Mw 7.4 inland earthquake in Hatay Province of Turkey, which would trigger a submarine landslide generating a tsunami, mainly impacting Iskenderun Bay, but also leading to tsunami impacts in various locations in the Eastern Mediterranean (Figure 8). NEAMWave17 was the first tsunami exercise to be conducted by KOERI, CENALT, INGV and NOA as accredited tsunami service providers. The main aim was to simulate a multihazard natural 
disaster in a region where there is an ongoing humanitarian crisis to allow phase B and phase $C$ participants to consider respective actions. In this respect, it should be noted that more than 3,800,000 Syrian refugees are hosted in Turkey, with more than 35,000 Syrian refugees sheltered by the Turkish CPA AFAD in Hatay Province alone. Through this exercise, KOERI-RETMC performed a final full-scale testing of its in-house-developed tsunami analysis and message dissemination software "TsuComp", as supported by the FP-7 Project "ASTARTE”, prior to its operationalization on 1 January 2018.
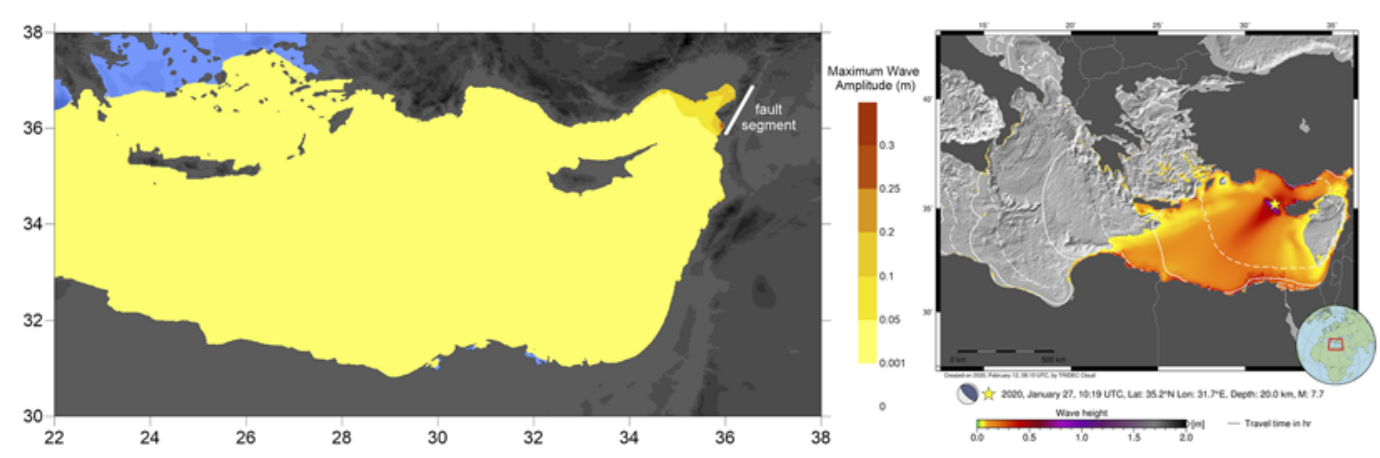

Figure 8. (left) Distribution of maximum water surface elevation due to $3 \mathrm{~h}$ simulation of the submarine landslide generated tsunami triggered by a Mw 7.4 scenario earthquake (corresponding fault line is shown as a white bar) in NEAMWave17 [27]. (right) Initial tsunami conditions, distribution of maximum wave height and wave travel times for the KOERI-NOA NEAMWave21 scenario [28].

\subsubsection{NEAMWave21}

NEAMWave21 [28], the 4th Tsunami exercise conducted by ICG/NEAMTWS, was held on 8-10 March 2021, during the week corresponding to the 10th anniversary of the 11 March 2011 Tohoku earthquake and tsunami. The exercise scenario, designed in collaboration with NOA (Greece), was based on a Mw 7.7 earthquake offshore of Cyprus, aiming to consolidate the objectives of the NEAMWave17 exercise (Figure 8). Seven messages were disseminated by KOERI-TSP on 8 March 2021 within a $4 \mathrm{~h}$ period to the subscribers of the exercise. The modeling of the KOERI-NOA scenario was done by KOERI through the Easy Wave [29] tsunami modeling tool embedded in GFZ's TRIDEC Cloud, which is a cloud- and web-based prototype tsunami early warning decision support platform based on the experiences and knowledge gained in the above-mentioned FP7 TRIDEC Project $[24,25,30,31]$.

\section{An Overview of the Operational Performance}

A map and full list of events that necessitated dissemination of tsunami bulletins by KOERI-RETMC since its operationalization as a candidate tsunami service provider in 2012 are provided in Figure 9 and Table 2, respectively. In 34 out of the total of 38 events, tsunami bulletins were disseminated successfully. From those successfully sent bulletins, 31 bulletins were issues at the correct alert level with respect to the decision matrix. From those, 23 bulletins were at the 'information' level, 6 at the 'advisory' level and 5 at the 'watch' level. In 4 events, 3 messages in 2012 were not disseminated because of exceedance of the target message dissemination time of $15 \mathrm{~min}$ in accordance with the SOPs defined at that time, while 1 message (18 May 2020 Crete $5.7 \mathrm{Mw}$ ) was not disseminated due to a duty officer error. The average message dissemination latency was $9.6 \mathrm{~min}$. The average magnitude difference between the magnitude issued by KOERI-RETMC in the tsunami bulletin and the USGS final magnitude was 0.2 . The average difference in the epicentral location, hypocentral depth and hypocentral distance between KOERI and USGS solutions remained satisfactory at $14 \mathrm{~km}, 7 \mathrm{~km}$ and $18 \mathrm{~km}$, respectively. 


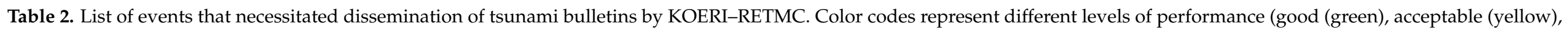

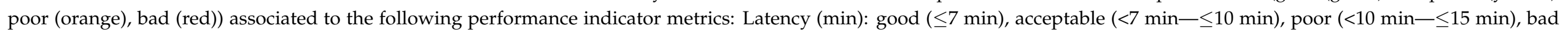

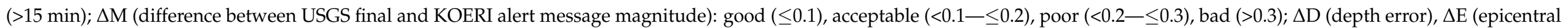

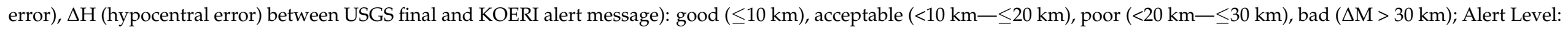
good (correct), bad (wrong).

\begin{tabular}{|c|c|c|c|c|c|c|c|c|c|c|c|c|c|c|c|c|c|c|}
\hline $\begin{array}{c}\text { Event } \\
\text { \# }\end{array}$ & $\begin{array}{c}\text { Message } \\
\#\end{array}$ & Date & $\begin{array}{l}\text { UTC } \\
\text { Time }\end{array}$ & Location & $\begin{array}{l}\text { Latitude } \\
\text { (KOERI) }\end{array}$ & $\begin{array}{c}\text { Longtitude } \\
\text { (KOERI) }\end{array}$ & $\begin{array}{l}\text { Latitude } \\
\text { (USGS) }\end{array}$ & $\begin{array}{c}\text { Longtitude } \\
\text { (USGS) }\end{array}$ & $\begin{array}{c}\Delta \text { Epicenter } \\
(\Delta \mathrm{E})\end{array}$ & 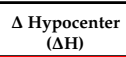 & $\begin{array}{c}\text { Depth } \\
\text { (KOERI) }\end{array}$ & $\begin{array}{l}\text { Depth } \\
\text { (USGS) }\end{array}$ & $\begin{array}{l}\Delta \text { Depth } \\
(\Delta \mathrm{D})\end{array}$ & $\begin{array}{c}\begin{array}{c}\text { Magnitude } \\
\text { (KOERI-TSP) }\end{array} \\
\text { (KO) }\end{array}$ & $\begin{array}{c}\text { Magnitude } \\
\text { (USGS) }\end{array}$ & $\begin{array}{c}\Delta \text { Magnitude } \\
(\Delta \mathrm{M})\end{array}$ & Alert Level & $\begin{array}{c}\text { Latency } \\
(\mathrm{min})\end{array}$ \\
\hline 1 & $\mathrm{~N} / \mathrm{A}$ & 9 July 2012 & 13:55 & Eastern Mediterranean & 35.51 & 28.99 & 35.604 & 28.919 & 12.3 & 36.8 & 21.1 & 55.8 & -34.7 & $6.0 \mathrm{ML}$ & $5.6 \mathrm{mww}$ & 0.4 & $\mathrm{~N} / \mathrm{A}$ & $\mathrm{N} / \mathrm{A}$ \\
\hline 2 & N/A & 12 September 2012 & $03: 27$ & Eastern Mediterranean & 34.48 & 23.99 & 34.783 & 24.11 & 35.4 & 41.9 & 10 & 32.4 & -22.4 & $5.5 \mathrm{ML}$ & $5.5 \mathrm{mww}$ & 0.0 & $\mathrm{~N} / \mathrm{A}$ & $\mathrm{N} / \mathrm{A}$ \\
\hline 3 & N/A & 23 December 2012 & 13:31 & Black Sea & 42.49 & 41.02 & 42.42 & 41.075 & 9.0 & 13.6 & 5 & 15.2 & -10.2 & $5.8 \mathrm{Mw}(\mathrm{mB})$ & $5.7 \mathrm{mww}$ & 0.1 & N/A & N/A \\
\hline 4 & 1 & 8 January 2013 & $14: 16$ & Aegean Sea & 39.66 & 25.53 & 39.656 & 25.54 & 1.0 & 3.0 & 10 & 12.8 & -2.8 & $6.2 \mathrm{ML}$ & $5.7 \mathrm{mww}$ & 0.5 & INFORMATION & 29 \\
\hline 5 & 2 & 17 January 2013 & 21:17 & Egypt & 31.75 & 30.45 & 32.027 & 30.624 & 34.9 & 36.3 & 10 & 20.0 & -10 & $5.5 \mathrm{Mw}(\mathrm{mB})$ & $4.9 \mathrm{mb}$ & 0.6 & INFORMATION & 9 \\
\hline 6 & 3 & 17 February 2013 & 03:12 & Ionian Sea & 37.33 & 20.74 & 37.329 & 20.74 & 0.1 & 6.4 & 10 & 3.6 & 6.4 & 5.4 & $4.9 \mathrm{mb}$ & 0.5 & INFORMATION & 6 \\
\hline 7 & 4 & 15 June 2013 & 16:11 & Crete & 34.19 & 24.88 & 34.4 & 25.02 & 26.7 & 26.7 & 10 & 10.0 & 0 & $6.0 \mathrm{Mw}(\mathrm{mB})$ & $6.2 \mathrm{Mwp}$ & 0.2 & INFORMATION & 6 \\
\hline 8 & 5 & 16 June 2013 & $21: 39$ & Crete & 34.16 & 24.97 & 34.347 & 25.159 & 27.1 & 28.6 & 10 & 19.0 & -9 & $5.9 \mathrm{Mw}(\mathrm{mB})$ & $6.0 \mathrm{mww}$ & 0.1 & INFORMATION & 6 \\
\hline 9 & 6 & 12 October 2013 & 13:11 & Grece & 35.56 & 23.31 & 35.5142 & 23.2523 & 7.3 & 10.1 & 47 & 40.0 & 7 & $6.4 \mathrm{Mw}$ & $6.6 \mathrm{mww}$ & 0.2 & WATCH & 14 \\
\hline 10 & 7 & 28 December 2013 & 15:21 & Antalya Bay-Turkey & 35.95 & 31.27 & 36.028 & 31.31 & 9.4 & 32.1 & 10 & 40.7 & -30.7 & $6.1 \mathrm{Mwp}$ & $5.9 \mathrm{mww}$ & 0.2 & INFORMATION & 6 \\
\hline 11 & 8 & 24 May 2014 & 09:25 & Aegean Sea & 40.24 & 25.33 & 40.2893 & 25.3889 & 7.4 & 18.2 & 23 & 6.4 & 16.57 & $6.6 \mathrm{Mw}$ & $6.9 \mathrm{Mw}$ & 0.3 & WATCH & 18 \\
\hline 12 & 9 & 29 August 2014 & 03:45 & Aegean Sea & 36.63 & 23.54 & 36.685 & 23.706 & 16.0 & 17.1 & 86 & 80.0 & 6 & $5.6 \mathrm{Mw}$ & $5.8 \mathrm{mww}$ & 0.2 & INFORMATION & 9 \\
\hline 14 & 11 & 12 June 2017 & $12: 28$ & Lesbos & 38.83 & 26.32 & 38.9296 & 26.365 & 11.7 & 11.9 & 10 & 12.0 & -2 & $6.3 \mathrm{Mwp}$ & $6.3 \mathrm{mww}$ & 0.0 & ADVISORY & 10 \\
\hline 15 & 12 & 20 July 2017 & $22: 31$ & Bodrum-Kos & 36.96 & 27.51 & 36.9293 & 27.4139 & 9.2 & 10.0 & 11 & 7.0 & 4 & $6.6 \mathrm{Mw}$ & $6.6 \mathrm{mww}$ & 0.0 & WATCH & \\
\hline 16 & 13 & 5 February 2019 & $02: 26$ & Albania & 39.07 & 20.54 & 39.052 & 20.5868 & 4.5 & 5.0 & 10 & 7.7 & 2.27 & $5.6 \mathrm{Mw}$ & $5.4 \mathrm{mww}$ & 0.2 & INFORMATION & 5 \\
\hline 17 & 14 & 20 March 2019 & $06: 34$ & Aydin-Turkey & 37.45 & 29.43 & 37.4078 & 29.531 & 10.1 & 14.9 & 19 & 8.0 & 11 & $5.8 \mathrm{Mwp}$ & $5.7 \mathrm{mww}$ & 0.1 & INFORMATION & 13 \\
\hline 18 & 15 & 1 June 2019 & $04: 26$ & Greece-Albania & 40.48 & 20.51 & 40.5257 & 20.7025 & 17.1 & 17.1 & 10 & 10.0 & 0 & $5.5 \mathrm{Mwp}$ & $5.2 \mathrm{mww}$ & 0.3 & INFORMATION & 8 \\
\hline 19 & 16 & 19 July 2019 & $11: 13$ & Greece & 38.11 & 23.51 & 38.0951 & 23.5251 & 2.1 & 10.2 & 20 & 10.0 & 10 & $5.5 \mathrm{Mwp}$ & $5.3 \mathrm{mww}$ & 0.2 & INFORMATION & 9 \\
\hline 20 & 17 & 21 September 2019 & 14:04 & Albania & 41.34 & 19.42 & 41.3375 & 19.5303 & 9.2 & 9.2 & 20 & 20.0 & 0 & $5.8 \mathrm{Mw}$ & $5.6 \mathrm{mww}$ & 0.2 & INFORMATION & 9 \\
\hline 21 & 18 & 26 September 2019 & 10:59 & Marmara Sea & 40.83 & 28.17 & 40.9035 & 28.1502 & 8.3 & 8.6 & 10 & 8.0 & 2 & $5.7 \mathrm{Mwp}$ & $5.7 \mathrm{mww}$ & 0.0 & INFORMATION & 8 \\
\hline$\frac{21}{22}$ & 19 & 26 November 2019 & $02: 54$ & Albania & 441.39 & 19.41 & 41.5138 & 19.5256 & 16.8 & 20.6 & 10 & 22.0 & -12 & $6.5 \mathrm{Mwp}$ & $6.4 \mathrm{mww}$ & 0.1 & WATCH & $\frac{8}{6}$ \\
\hline 23 & 20 & 27 November 2019 & $07: 23$ & Crete & 35.53 & 23.11 & 35.7174 & 23.2284 & 23.4 & 23.5 & 71 & 69.0 & 2 & $6.1 \mathrm{Mwp}$ & $6.0 \mathrm{mww}$ & 0.1 & ADVISORY & 9 \\
\hline 24 & 21 & 10 December 2019 & $21: 58$ & Crete & 35.1 & 26.34 & 35.4972 & 26.4467 & 45.2 & 52.0 & 83.5 & 57.9 & 25.6 & $5.7 \mathrm{Mw}$ & $5.4 \mathrm{mww}$ & 0.3 & INFORMATION & 9 \\
\hline 25 & 22 & 30 January 2020 & $01: 28$ & Dodecanese Islands & 35.13 & 27.94 & 35.1565 & 27.8845 & 5.8 & 5.8 & 10 & 10.0 & 0 & $6.1 \mathrm{Mwp}$ & $5.5 \mathrm{mww}$ & 0.6 & ADVISORY & 7 \\
\hline 26 & 23 & 30 January 2020 & 11:21 & Dodecanese Islands & 35.08 & 27.79 & 35.1817 & 27.7814 & 11.3 & 11.3 & 10 & 10.0 & 0 & $5.8 \mathrm{Mwp}$ & $5.7 \mathrm{mww}$ & 0.1 & INFORMATION & 8 \\
\hline 28 & N/A & 18 May 2020 & $23: 22$ & Crete & 34.14 & 25.53 & 34.1855 & 25.5173 & 5.2 & 7.2 & 5 & 10.0 & -5 & $5.6 \mathrm{Mwp}$ & $5.7 \mathrm{mww}$ & 0.1 & N/A & N/A \\
\hline 30 & 26 & 20 May 2020 & 23:43 & Crete & 35.07 & 20.25 & 35.1594 & 20.2775 & 10.3 & 10.8 & 10 & 13.5 & -3.5 & $5.7 \mathrm{Mwp}$ & $5.7 \mathrm{mww}$ & 0.0 & INFORMATION & 8 \\
\hline 31 & 27 & 18 September 2020 & $16: 28$ & Crete & 34.71 & 25.18 & 35.0368 & 25.3034 & 38.0 & 39.1 & 35 & 44.0 & -9 & $5.8 \mathrm{Mwp}$ & $5.9 \mathrm{mww}$ & 0.1 & INFORMATION & 7 \\
\hline 32 & 28 & 30 October 2020 & $11: 51$ & Samos Island & 37.89 & 26.83 & 37.8973 & 26.7838 & 4.1 & 11.8 & 10 & 21.0 & -11 & $7.0 \mathrm{Mwp}$ & $7.0 \mathrm{mww}$ & 0.0 & WATCH & 11 \\
\hline 33 & 29 & 3 March 2021 & 10:16 & Greece & 39.8 & 22.16 & 39.7546 & 22.1757 & 5.2 & 5.6 & 10 & 8.0 & 2 & $6.3 \mathrm{Mwp}$ & $6.3 \mathrm{mww}$ & 0.0 & INFORMATION & 9 \\
\hline 34 & 30 & 21 June 2021 & $22: 14$ & Dodecanese Islands & 36.37 & 27.08 & 36.4391 & 27.0416 & 8.4 & 8.9 & 12 & 9.0 & 3.0 & $5.6 \mathrm{Mwp}$ & $5.5 \mathrm{mww}$ & 0.1 & INFORMATION & 8 \\
\hline 35 & 31 & 1 August 2021 & $04: 31$ & Dodecanese Islands & 36.34 & 27.06 & 36.3958 & 27.0112 & 7.6 & 10.2 & 17 & 10.1 & 6.9 & $5.8 \mathrm{Mwp}$ & $5.6 \mathrm{mww}$ & 0.2 & INFORMATION & 8 \\
\hline 36 & 32 & 27 September 2021 & 06:17 & Crete & 35.17 & 25.22 & 35.244 & 25.2697 & 9.4 & 10.2 & 10 & 6.0 & 4 & $6.1 \mathrm{Mwp}$ & $6.0 \mathrm{mww}$ & 0.1 & ADVISORY & 13 \\
\hline 37 & 33 & 12 October 2021 & $09: 24$ & Crete & 34.91 & 26.26 & 35.1693 & 26.2163 & 29.1 & 29.5 & 15 & 20.0 & -5 & $6.2 \mathrm{Mwp}$ & $6.4 \mathrm{mww}$ & 0.2 & ADVISORY & 6 \\
\hline 38 & 34 & 19 October 2021 & $05: 32$ & Crete & 34.46 & 28.35 & 34.5883 & 28.3882 & 14.7 & 34.8 & 10 & 41.5 & & $6.0 \mathrm{Mwp}$ & $5.9 \mathrm{mww}$ & 0.1 & INFORMATION & 9 \\
\hline
\end{tabular}




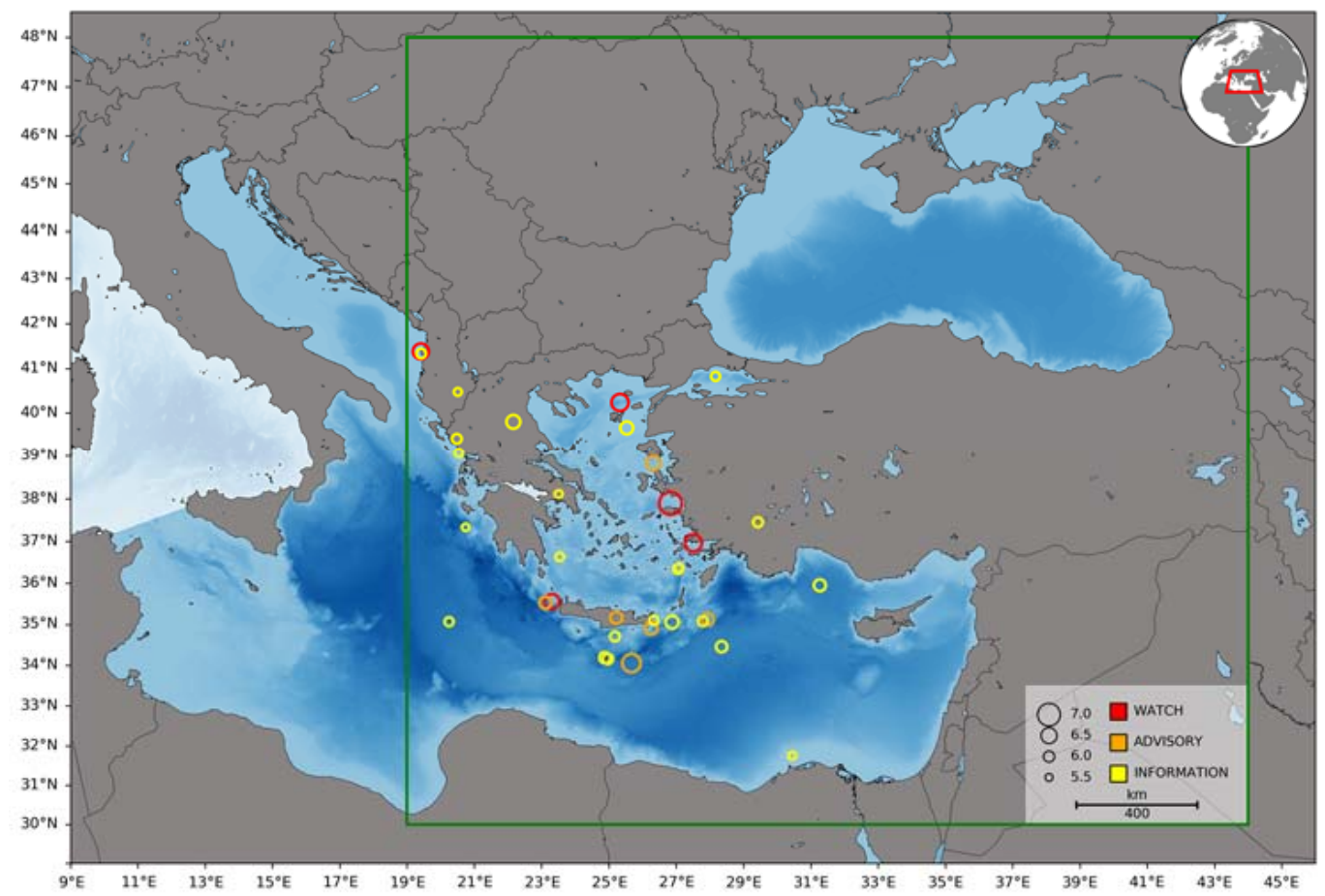

Figure 9. Events with magnitudes and corresponding alert levels for the events in the Eastern Mediterranean that necessitated dissemination of tsunami bulletins by KOERI-RETMC since its operationalization as a candidate tsunami service provider as of 1 July 2012.

As in all systems in the operational environment, KOERI-TSP has also experienced some erroneous actions and outages during its history. In 2014, two erroneous earthquake notifications were sent to KOERI's subscribers for events outside its service area, namely in the Southern Indian Ocean and Vanuatu Islands, respectively. A similar problem was again encountered in 2015 for an earthquake in the South Sandwich Islands. A monthly communication test was sent erroneously on the wrong day in October 2015. A scenario-based exercise message concerning an earthquake in the Jordan-Syria region was sent erroneously during daily system tests in January 2018. Due to an infrastructure problem effecting primary and backup communication channels, KOERI-TSP services were interrupted for $14 \mathrm{~h}$ during November 2019. A similar problem was experienced in July 2021, resulting in a service outage of 6 h. In July 2021, a 'cancellation' message was sent out erroneously as a real message by the duty officer during a regular internal tsunami exercise.

\section{Lessons Learnt from Recent Tsunami Events}

\subsection{July 2017 Bodrum-Kos Earthquake and Tsunami}

An assessment of the operational performance of NEAMTWS-TSPs for this event was discussed in detail in [32]. Although the Mw 6.6 Bodrum-Kos earthquake and resulting tsunami was moderate with little damage to properties, it was the first noticeable tsunami in the Mediterranean Basin since the tsunami triggered by the 21 May 2003 Boumerdès Mw 6.8 earthquake in the Western Mediterranean. Tsunami warnings were issued by INGV (Italy) within $10 \mathrm{~min}$, by NOA (Greece) within $18 \mathrm{~min}$ and by KOERI (Turkey) within $19 \mathrm{~min}$. Apart from INGV, the responses from NOA and KOERI were not adequate enough to trigger any potential tsunami evacuation in the Bodrum-Kos area. Post-mortem analysis revealed that for KOERI, the instability of the earthquake magnitude determined through the automatic systems was the main result of the message dissemination latency. This event led to the revision of the duty officer's SOP and an additional visual interface was 
developed and installed in the operational system, which would allow the duty officer to visually investigate and compare various magnitude values of different types derived from automatic sources, so that the earthquake magnitude can be selected from this interface directly and a corresponding tsunami message can be created and disseminated. As pointed out in [32], even if a warning time of $\sim 10 \mathrm{~min}$ was achieved by KOERI and NOA, it would not have led to any evacuation, simply due to the fact that there was (and still is) no publicly available tsunami warning infrastructure, which remains the major responsibility of the respective civil protection authorities. Another striking aspect is that the tsunami modeling results indicated two-fold nearshore maximum water elevations for an earthquake $\mathrm{Mw}$ of 6.8 , which is not an unlikely scenario for the Bodrum-Kos area. In addition, the tsunami could have resulted in loss of lives if the earthquake had happened during the daytime in the middle of the tourist season [33]. In fact, this event was a bitter reminder of the inefficiencies of NEAMTWS in dealing with local and near-field tsunami threats and the need for possible supplementary mechanisms [34,35].

\subsection{October 2020 Samos-Izmir Earthquake and Tsunami}

Following the Mw 7.0 Izmir-Samos earthquake on 30 October 2020, INGV's message was disseminated $8 \mathrm{~min}$ after the event, followed by KOERI and NOA's messages $11 \mathrm{~min}$ after the earthquake origin time [36]. The generated tsunami arrived within about ten minutes on the NW coast of Samos Island and within 20 min on the coast of Turkey, where one person died due to the tsunami and significant damage was caused to coastal infrastructure [36-39]. Examples of enhanced products (i.e., distance-based tsunami alert map, tsunami forecast point alert level map and tsunami travel map) attached to the alert messages sent by KOERI-TSP during the event are given in Figure 6. The short arrival time left a very narrow window for the coastal population to evacuate and move to higher ground, not to mention an impossibly small window for TSP messages to be delivered and acted upon by local authorities [36]. Similar to the 2017 Bodrum-Kos earthquake and tsunami, this event again highlighted the need to support the current NEAMTWS architecture with local tsunami warning systems and disaster education programs. One relatively comforting aspect of this event was that the tsunami did not impact İzmir, which was rather heavily affected by the earthquake, with hundreds of buildings either collapsing or being heavily damaged, costing 116 lives in Turkey [36]. A combination of both earthquake and tsunami impacts at the same time could have increased the number of fatalities significantly, not only in terms of loss of life for those trapped under collapsed buildings, but also eliminating any realistic possibility of vertical evacuation.

\section{Discussions and Conclusions Regarding Gaps and Areas of Improvement in the System}

The key operational functions of a tsunami warning center are to provide real-time monitoring and seismic and tsunami activity alerts and to allow timely decision-making and the dissemination of tsunami warnings, advisories and information. The chain begins with data collection and ends with saving lives [40]. Despite the efforts made to establish an end-to-end tsunami warning system in Turkey, meaningful progress has only been made for the upstream system component. There is simply no real operational capability of the Civil Protection Authority of Turkey (AFAD) to analyze and forward tsunami warning messages received from KOERI-TSP to its local units and the public or to warn the public directly in cases of tsunamigenic events. However, the 30 October 2020 Samos earthquake and resulting tsunami effecting the southern coasts of the İzmir peninsula appears to be milestone in this aspect. A direct emergency telephone line was established in 2021 between RETMC and AFAD to allow verbal communication between agencies in case of a tsunami alert, and efforts are underway by the AFAD to establish a nationwide integrated warning and alarm system as part of a wider disaster management and decision support system. While it is obvious that an effective tsunami warning system can be achieved only through various awareness, education, preparedness and mitigation activities, focusing 
on the downstream components of the system, such elements are beyond the scope of this paper.

The current distribution and density of tide gauges could be very problematic for the verification of a tsunami after an earthquake, as experienced during the tsunami observations after the 30 October 2020 Samos earthquake. The difficulties in identifying the authenticity and reliability of eye witness observations distributed through the social media after a natural disaster add to this gap. This gap is even bigger around the southern coasts of the Mediterranean, requiring urgent action towards international agreements for the densification of tide gauges wherever possible. Such systems could also be designed from a multi-hazard perspective to ensure efficiency, sustainability and usability by various scientific and operational actors involved in natural disasters. There is also an urgent need for the deployment of offshore tsunami measurement systems, involving either ocean bottom pressure gauge or GPS buoy systems at optimum locations, as demonstrated in [41].

It is obvious that all TSP warning messages are subject to uncertainties related to the derivation of earthquake parameters and the decision support systems themselves, especially for decision-matrix based systems where a 0.1 unit change in the earthquake magnitude may drastically change the threat level to the assigned regions. The impacts of such a situation were easily observed during the 30 October 2021 Samos earthquake. The initial tsunami warning message disseminated by KOERI indicated a Mw 7.0 earthquake (also the final Mw published by the USGS), while the final Mw determined was Mw 6.9. As can be seen from Figure 6, the initial warning disseminated based on a Mw 7.0 event puts the whole Aegean Sea under the highest alert level. A tsunami warning message based on a Mw 6.9 event (Figure 7), if calculated at the time of the issuance of the initial message, would correspond quite accurately to the actual impact of the generated tsunami.

Offshore and coastal wave amplitudes for both cases derived from the MOD2-TR tsunami scenario database [20,21] are presented in Figure 10, clearly showing differences in comparison to the cases presented in Figures 6 and 7. This demonstrates the added value of making use of pre-calculated tsunami scenario databases for the purposes of tsunami warnings. However, the results available from pre-calculated tsunami scenario databases or near-real-time tsunami modeling may still carry uncertainties associated with the source of the tsunami. It would not be realistic at all to expect that rupture heterogeneities, the variation of the slip and where the highest (tsunamigenic) slip is concentrated in a given earthquake could be captured realistically in a pre-calculated tsunami scenario database or in real time. Moreover, pre-calculated deterministic tsunami databases may lead to erroneous results for tectonic regions where the dominant fault orientation cannot be determined easily due to a lack of instrumental data or geologic evidence, which is an important limitation for faults buried under the seabed. Computational advancements may allow the realization of near-real-time tsunami modeling in an operational tsunami warning system with an additional delay for the initial tsunami warning of less than one minute. However, the real added value of near-real-time modeling-based tsunami warnings for a region where the sources are mostly local or near-field is not the initial tsunami early warning, but rather the assessment and evaluation of the tsunami that is generated. The availability of such a system could allow a tsunami warning center to dynamically compare sea level observations, especially where the spatial density is high, and to make use of the updated source parameters on the spot to rapidly update and improve the tsunami forecast after the initial tsunami warning has been disseminated [42].

While recent efforts have focused on the use of probabilistic methods [43] to overcome the uncertainties associated with the deterministic approaches, whether through a decision matrix, pre-calculated tsunami scenario databases or near-real-time tsunami modeling, the real problem is on the side of the downstream component [44], namely the civil protection authorities, who have the responsibility of initiating tsunami evacuation orders. The uncertainty in the upstream component of the tsunami warning system cannot be avoided, unless all TSPs are synchronized in such a way that a unique warning message could be produced, which would correspond to an ill-formulization of the interoperability concept. 
Regardless of the type or content of the tsunami warning message, it is the analysis and interpretation capability of the message recipient as either a NTWC or TWFP that plays the key role in saving lives. It is also likely that divergent information from different TSPs could very well serve as a useful indicator of the degree of uncertainty for the end-user, meaning the problem could then be formulated so that SOPs could be followed by the message recipient [44]. Hence, efforts should focus on capacity-building programs targeting civil protection authorities or government agencies with national responsibility, such as NTWCs or TWFPs.
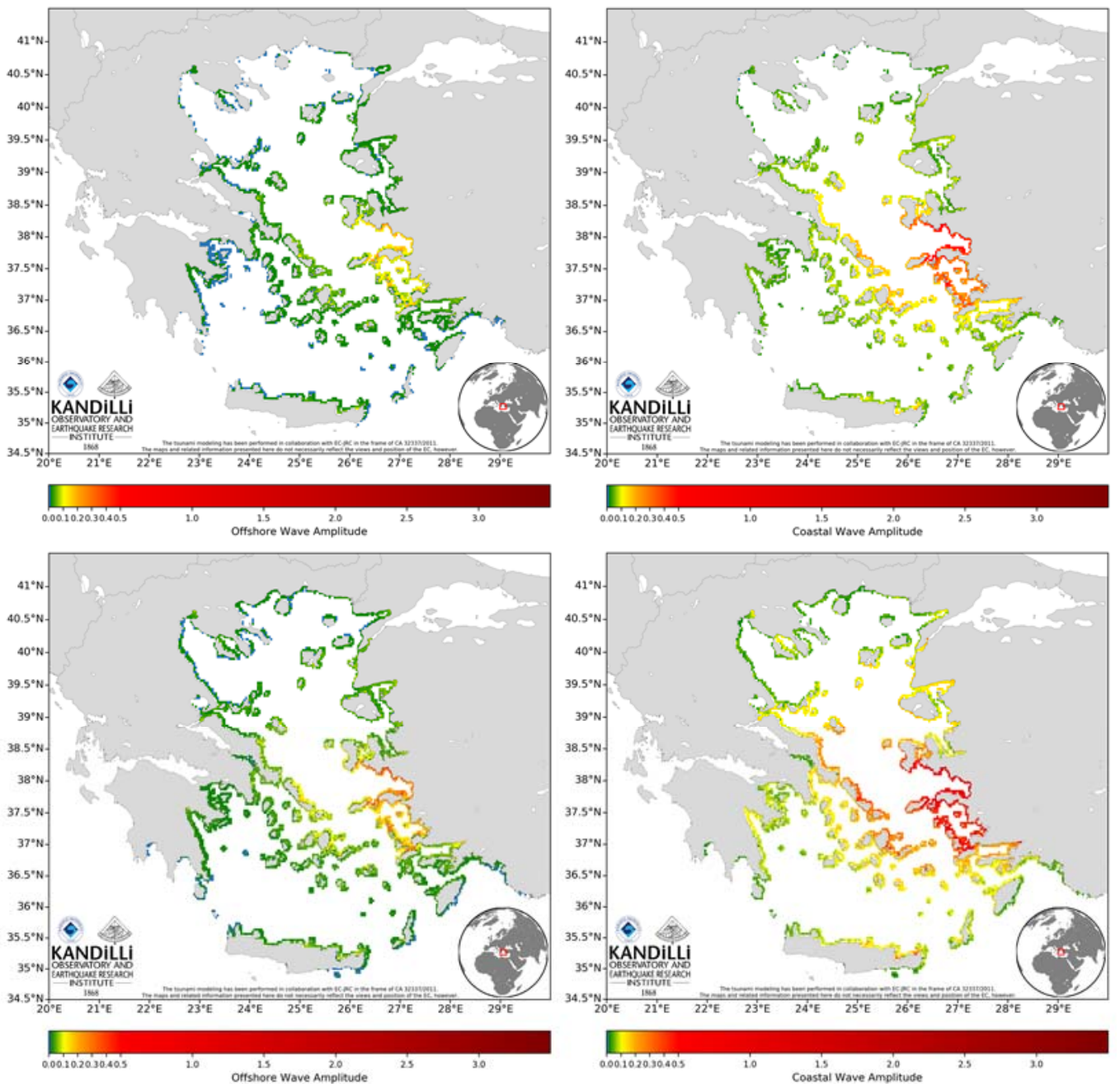

Figure 10. A comparison of offshore (actual value calculated in the last "wet" cell in tsunami modeling) (left) and coastal (projection of the offshore wave amplitude to the coast line through Green's law approximation) (right) wave amplitudes derived from MOD2-TR tsunami scenario database [20,21] for the 30 October 2020 Samos earthquake, with Mw 6.9 (top) and Mw 7.0 (bottom) being the final initial Mw values, respectively, used by KOERI in the tsunami warning message.

The classical tsunami warning methodology depends on the reliable identification of the location, depth and magnitude of an earthquake, which dictates $>7 \mathrm{~min}$ for the issuance of the initial tsunami warning with acceptable reliability, which may be still late for some coastal locations in the Eastern Mediterranean and Aegean Seas, where the tsunamigenic earthquake sources are located very near to the shoreline, as experienced once more during the 30 October $2020 \mathrm{Mw} 6.9$ earthquake. Local tsunami warning systems [33-35] triggered by the exceedance of a pre-determined acceleration value could reduce the warning time down to $<1 \mathrm{~min}$ and could help the evacuation process, especially in coastal communities with low awareness of the tsunami threat after a strong earthquake. In fact, the inadequacy of a centralized tsunami warning system based on earthquake parameters 
can only be remedied through local tsunami warning systems embedded in the NTWC/TSP operational framework and closely coupled with dedicated local or community-based tsunami awareness and preparedness campaigns involving all stakeholders.

KOERI's tsunami warning system has been operational for a decade now, and as reflected above, it has continuously improved in terms of its capabilities and performance. As of today, it is still the only NEAMTWS TSP disseminating enhanced products to its subscribers to allow rapid identification of the corresponding tsunami threat level. The tsunami warning system chain, however, is simply not complete at the national or international level. At the national level, the warning messages disseminated by KOERI-TSP do not reach its target - the people-a responsibility that is still must be resolved by the national civil protection authority-AFAD. To achieve this, there is an urgent need to initiate a national campaign to develop tsunami inundation and evacuation maps for coastal regions as part of disaster risk management strategy, whereby the tsunami threat is considered to be higher, together with public awareness and education programs. At the international level, capacity-building programs targeting TWFPs of NEAMTWS countries with no NTWC capability should be promoted through the IOC, noting that such programs could in principle also serve in the densification of the tide gauge network. International cooperation through initiatives such as the NATO Science for Peace and Security (SPS) program could help TSPs to deploy offshore tsunami measurement systems within NEAMTWS to improve the tsunami detection and verification capability. Such efforts could also be supported by the European Commission. Recognizing that every minute counts when dealing with tsunami threats, the development and deployment of local tsunami early warning systems as part of NTWCs should be encouraged to address the deficiencies of the NEAMTWS architecture, which depends on the earthquake magnitude. Such efforts should also consider seasonal demographic changes as a function of tourism. As demonstrated above, whether pre-calculated or computed in near-real-time, the feasibility of modeling-based tsunami early warning systems needs to be further explored, especially taking advantage of improvements in computational capability. Efforts towards making use of probabilistic methodologies for tsunami early warning systems should continue, cautiously noting the need for specific training and capacity-building programs for the recipients of such warnings, especially recognizing the fact that the uncertainties of deterministic methodologies could be easier for the recipients to deal with than the uncertainties associated with probabilistic methodologies. Lastly, even though stand-alone systems such as in Stromboli and the Adriatic Sea exist, they have neither been validated nor accredited, also noting that NEAMTWS has traditionally limited itself to earthquake-generated tsunamis and does not currently consider tsunamis from atypical sources in its operational setting, such as tsunamis generated by landslides and volcanic activities and those of meteorological origin. While recognizing the ongoing efforts to address these deficiencies, a paradigm shift regarding this aspect is highly recommended.

Author Contributions: Ö.N. was the primary coordinator for KOERI-TSP during 2009-2021 and was involved in the conceptualization, methodology, software design, validation, analysis, exercises, testing and performance monitoring of the system, together with drafting this manuscript as the lead author. F.T. contributed significantly to the operationalization, maintenance, testing, software implementation, development and improvement, exercises, testing and performance monitoring of the system, including Early-est and SeisComp software, and prepared most of the figures in this manuscript. C.Ö.S. contributed significantly to the establishment of the system and the relevant internal capacity-building program targeting the duty officers during her employment at KOERI in 2012-2017, and also contributed to the improvement of the manuscript. M.Y. was the prime developer of the TsuComp used in KOERI-TSP operations. Y.G. was mainly responsible for the operational sustainability of the system, communication test exercises and performance monitoring of the system. M.D.C. was responsible for the seismic and sea level data repository, together with S.A.P. and T.E., and also contributed to exercises, testing and performance monitoring of the system and was part of the drafting process of this manuscript. S.A.P. was responsible for the coordination of the sea level observation network-related activities and contributed to the manuscript in that aspect. T.E. coordinated activities related to SeisComP and its performance and contributed to the 
manuscript in that aspect. D.K. was the supervisor of the RETMC and was mainly responsible for administrative issues related to the implementation of the technical requirements of the system. As the Director of KOERI, H.Ö. was the project administrator and financial executive and was involved in the establishment of the tsunami warning system in 2015. All authors have read and agreed to the published version of the manuscript.

Funding: The establishment of RETMC was supported through a project funded by the Office of the President of Turkey-Presidency of Strategy and Budget (2014K 140200) and benefited from various EC-FP7 projects, such as TRIDEC - Collaborative, Complex and Critical Decision Support in Evolving Crises (GA 258723); MARSite-New Directions in Seismic Hazard Assessment through Focused Earth Observation in the Marmara Supersite (GA 308417); and ASTARTE-Assessment, Strategy And Risk Reduction for Tsunamis in Europe (GA 603839).

Institutional Review Board Statement: Not applicable.

Informed Consent Statement: Not applicable.

Data Availability Statement: Data presented in this manuscript may not be fully available publicly.

Acknowledgments: We would like to thank the European Commission-Joint Research Center (EC-JRC); General Directorate of Mapping (HGM); Ministry of Interior-Disaster and Emergency Management Presidency (AFAD); Office of Navigation, Hydrography and Oceanography (SHOD); and the State Meteorological Service (MGM) for their support for KOERI's tsunami warning system throughout the years. We would like to express our sincere gratitude to Nurcan Meral Özel for her visionary leadership and pioneering work as the foundation's project executive in the establishment of the tsunami warning system in Turkey. We would like to especially recognize the following individuals in alphabetical order for their key roles in that endeavor: Ahmet Cevdet Yalçıner, Alessandro Annunziato, Cemil Gürbüz, Gülay Altay, Gülay Barbarosoğlu and Mustafa Erdik. We would like to thank Ali Pınar for his leadership in RETMC during 2015-2018 and would like to thankfully recognize ex-staff member of REMTC, Mustafa Çomoğlu, for his important contributions in the technical implementation of the system until his separation in 2017. We would like to thank Anthony Lomax and INGV for making Early-est available to KOERI for operational purposes. We would like to wholeheartedly thank UNESCO/IOC-NOAA International Tsunami Information Center for making the Tsunami Travel Time (TTT) software available to KOERI. We are thankful to all staff members of RETMC for all their contributions to its operational activities, listed here in alphabetical order: Ayşegül Köseoğlu, Doğan Aksarı, Filiz Özdemir, Kamuran Taylan Çevre, Kıvanç Kekovalı, Mehmet Kara, Mehmet Özer, Mehveş Feyza Akkoyunlu, Murat Suvarıklı, Muzaffer Gül, Özkan Çok, Pınar Deniz Hisarlı, Remzi Polat, Seda Işık, Suat Çetin, Uğur Mustafa Teoman and Zafer Ögüutçü. Last but not least, KOERI would like to express its sincere gratitude to UNESCOIntergovernmental Oceanographic Commission (IOC) and specifically to its Tsunami Secretariat for coordination, support and guidance provided in all aspects of NEAMTWS; to all distinguished colleagues of ICG/NEAMTWS; its past and present Officers and Steering Committee; and especially other NEAM tsunami service providers (CENALT, INGV, IPMA and NOA) for their collaboration in the establishment and improvement of the NEAMTWS.

Conflicts of Interest: The authors declare no conflict of interest.

\section{References}

1. Meral Ozel, N.; Necmioglu, O.; Yalciner, A.C.; Kalafat, D.; Mustafa, E. Tsunami hazard in the Eastern Mediterranean and its connected seas: Toward a Tsunami warning center in Turkey. Soil Dyn. Earthq. Eng. 2011, 31, 598-610. [CrossRef]

2. Schindelé, F.; Gailler, A.; Hébert, H.; Loevenbruck, A.; Gutierrez, E.; Monnier, A.; Roudil, P.; Reymond, D.; Rivera, L. Implementation and Challenges of the Tsunami Warning System in the Western Mediterranean. Pure Appl. Geophys. 2015, 172, 821-833. [CrossRef]

3. Amato, A.; Avallone, A.; Basili, R.; Bernardi, F.; Brizuela, B.; Graziani, L.; Herrero, A.; Lorenzino, M.C.; Lorito, S.; Mele, F.M.; et al. From Seismic Monitoring to Tsunami Warning in the Mediterranean Sea. Seismol. Res. Lett. 2021, 92, 1796-1816. [CrossRef]

4. Interim Operational Users Guide for NEAMTWS, Version 1.10. 2011. Available online: http:/ /www.ioc-tsunami.org/index.php? option=com_oe\&task=viewDocumentRecord\&docID=8129 (accessed on 17 November 2021).

5. Cambaz, M.D.; Turhan, F.; Yılmazer, M.; Kekovalı, K.; Necmioğlu, Ö.; Kalafat, D. An Investigation on the Evaluation of Seismic Network and Catalogue of Regional Earthquake-Tsunami Monitoring Center (RETMC-KOERI). Yerbilimleri 2019, 40, 110-135. 
6. Cambaz, M.D.; Turhan, F.; Y1lmazer, M.; Kekovalı, K.; Necmioğlu, Ö.; Kalafat, D. A Review on Kandilli Observatory and Earthquake Research Institute (KOERI) Seismic Network and Earthquake Catalog: 2008-2018. Adv. Geosci. 2019, 51, 15-23. [CrossRef]

7. Cambaz, M.D.; Özer, M.; Güneş, Y.; Ergün, T.; Öğütçü, Z.; Altuncu-Poyraz, S.; Köseoğlu, A.; Turhan, F.; Yilmazer, M.; Kekovali, K.; et al. Evolution of the Kandilli Observatory and Earthquake Research Institute (KOERI) Seismic Network and the Data Center Facilities as a Primary Node of EIDA. Seismol. Res. Lett. 2021, 92, 1571-1580. [CrossRef]

8. Kalafat, D. Statistical Evaluation of Turkey Earthquake Data (1900-2015): A Case study. East. Anatol. J. Sci. 2016, 2, 14-36.

9. Möllhoff, M.; Bean, C.J.; Baptie, B.J. SN-CAST: Seismic network capability assessment software tool for regional networksexamples from Ireland. J. Seismol. 2019, 23, 493-504. [CrossRef]

10. Hanka, W.; Saul, J.; Weber, B.; Becker, J.; Harjadi, P.; Fauzi; GITEWS Seismology Group. Real-time earthquake monitoring for tsunami warning in the Indian Ocean and beyond. Nat. Hazards Earth Syst. Sci. 2010, 10, 2611-2622. [CrossRef]

11. Olivieri, M.; Clinton, J. An Almost Fair Comparison between Earthworm and SeisComp3. Seismol. Res. Lett. 2012, 83, 720-727. [CrossRef]

12. Lomax, A.; Michelini, A. Mwpd: A duration-amplitude procedure for rapid determination of earthquake magnitude and tsunamigenic potential from P waveforms. Geophys. J. Int. 2009, 176, 200-214. [CrossRef]

13. Lomax, A.; Michelini, A. Tsunami early warning using earthquake rupture duration, Geophys. Res. Lett. 2009, 36, L09306. [CrossRef]

14. Lomax, A.; Michelini, A. Tsunami early warning using earthquake rupture duration and P-wave dominant period: The importance of length and depth of faulting, Geophys. J. Int. 2011, 185, 283-291. [CrossRef]

15. Lomax, A.; Michelini, A. Tsunami early warning within 5 minutes. Pure Appl. Geophys. 2012, 170, 1385-1395. [CrossRef]

16. Bernardi, F.; Lomax, A.; Michelini, A.; Lauciani, V.; Piatanesi, A.; Lorito, S. Appraising the Early-est earthquake monitoring system for tsunami alerting at the Italian Candidate Tsunami Service Provider. Nat. Hazards Earth Syst. Sci. 2015, 15, 1-40. [CrossRef]

17. Annunziato, A. The Inexpensive Device for Sea Level Measurements. Sci. Tsunami Hazards-J. Tsunami Soc. Int. 2015, $34,199$.

18. Flanders Marine Institute (VLIZ); Intergovernmental Oceanographic Commission (IOC). Sea Level Station Monitoring Facility. 2021. Available online: http://www.ioc-sealevelmonitoring.org (accessed on 17 November 2021).

19. The Inexpensive Device for Sea Level Measurements. Available online: https://webcritech.jrc.ec.europa.eu/TAD_server/Home (accessed on 17 November 2021).

20. Necmioglu, O.; Ozel, N.M. Earthquake Scenario-Based Tsunami Wave Heights in the Eastern Mediterranean and Connected Seas. Pure Appl. Geophys. 2015, 172, 3617-3638. [CrossRef]

21. Necmioğlu, Ö. Tsunami Hazard in Turkey and Surroundings. Ph.D. Thesis, Department of Geophysics, Kandilli Observatory and Earthquake Research Institute, Boğaziçi University, Istanbul, Turkey, 2014.

22. Wessel, P.; Smith, W.H.F.; Scharrop, R.; Luis, J.F.; Wobbe, F. Generic Mapping Tools: Improved version released. Eos Trans. AGU 2013, 94, 409-410. [CrossRef]

23. Annunziato, A.; Fonio, C.; Mugnai, F.; Galliano, D. Tsunami Decision Support Systems. TDSS-2015. In Outcomes of the 6th JRC ECML Crisis Management Technology Workshop; Publications Office of the European Union: Luxembourg, 2015.

24. Hammitzsch, M.; Carrilho, F.J.; Necmioglu, O.; Lendholt, M.; Reißland, S.; Schulz, J.; Omira, R.; Comoglu, M.; Ozel, N.M.; Wächter, J. Meeting UNESCO-IOC ICG/NEAMTWS requirements and beyond with TRIDEC's Crisis Management Demonstrator for Tsunamis. In Proceedings of the Twenty-third International Offshore and Polar Engineering Conference, Anchorage, AK, USA, 30 June-5 July 2013.

25. Necmioğlu, Ö.; Matias, L.M.; Schindelé, F.; Behrens, J.; Arthurton, R.; Tinti, S.; Rudloff, A.; Crochet, E.; Gonzalez, M.; Santoro, F.; et al. Exercise NEAMWave 12 A Tsunami Warning and Communication Exercise for the North-Eastern Atlantic, the Mediterranean, and Connected Seas Region, Exercise Manual and Evaluation Report; UNESCO Intergovernmental Oceanographic Commission Technical Series 103; UNESCO: Paris, France, 2012; Available online: https:/ / unesdoc.unesco.org/ark: / 48223/pf0000218990 (accessed on 17 November 2021).

26. Behrens, J.; Carrilho, F.; Crochet, E.; Gonzalez, M.; Guymer, T.; Imperiali, O.; Matias, L.M.; Melis, N.; Necmioğlu, O.; Santini, M.; et al. Exercise NEAMWave 14. A Tsunami Warning and Communication Exercise for the North-Eastern Atlantic, the Mediterranean, and Connected Seas Region, 28-30 October 2014, Volume I: Manual; IOC Technical Series No 114 Vol.1; UNESCO: Paris, France, 2014. (In English)

27. Özer Sözdinler, C.; Panunzi, E.; Imperiali, O.; Necmioğlu, O.; Santini, M.; Charalampakis, M.; Yalçıner, A.C.; Intergovernmental Oceanographic Commission. Tsunami Exercise NEAMWave17-A Tsunami Warning and Communication Exercise for the North-eastern Atlantic, the Mediterranean, and Connected Seas Region, 31 October-3 November 2017; Volume 1: Exercise Instructions; IOC Technical Series No.134 Vol.1; UNESCO: Paris, France, 2017. (In English)

28. Özer Sözdinler, C.; Charalampakis, M.; Gaite, B.; Romano, F.; Carrilho, F.; Kalligeris, N.; Necmioglu, O.; Roudil, P. NEAMWave 21 Tsunami Exercise. A Tsunami Warning and Communication Exercise for the North-Eastern Atlantic, the Mediterranean, and Connected Seas Region. Exercise Manual (Vol.1): Exercise Instructions (Part 1) and Exercise Supplements (Part 2); (IOC/2021/TS/164 Vol. 1); UNESCO: Paris, France, 2021; Available online: https:/ / unesdoc.unesco.org/ark:/48223/pf0000375341.locale=en (accessed on 17 November 2021).

29. Easy Wave. Available online: https:/ / gitext.gfz-potsdam.de/geoperil/easyWave (accessed on 17 November 2021). 
30. Hammitzsch, M.; Spazier, J.; Reißland, S.; Necmioglu, O.; Comoglu, M.; Sozdinler, C.O.; Carrilho, F.; Wächter, J. TRIDEC Cloud-A Web-based Platform for Tsunami Early Warning tested with NEAMWave14 Scenarios. In Proceedings of the EGU General Assembly Conference Abstracts 2015, Vienna, Austria, 12-17 April 2015.

31. TRIDEC Cloud. Available online: https:/ /trideccloud.gfz-potsdam.de/ (accessed on 17 November 2021).

32. Heidarzadeh, M.; Necmioglu, Ö.; Ishibe, T.; Yalciner, A.C. Bodrum-Kos (Turkey-Greece) Mw 6.6 earthquake and tsunami of 20 July 2017: A test for the Mediterranean tsunami warning system. Geosci. Lett. 2017, 4, 31. [CrossRef]

33. Necmioğlu, Ö.; Yalçıner, A.C.; Kalafat, D.; Süzen, L.; Tanırcan, G.; Annunziato, A.; Santini, M.; Güney Doğan, G.; Tüfekçi Enginar D.; Güneş, Y.; et al. Addressing Challenges and Requirements for Local Tsunami Awareness, Warning and Mitigation: A “Last Mile" Case Study for Bodrum-Turkey. In Proceedings of the 5th International Conference on Earthquake Engineering and Seismology, Ankara, Turkey, 8-11 October 2019.

34. Papadopoulos, G.A.; Fokaefs, A. Near-field tsunami early warning and emergency planning in the Mediterranean Sea. Res. Geophys. 2013, 3, 24-31. [CrossRef]

35. Necmioğlu, Ö. Design and challenges for a tsunami early warning system in the Marmara Sea. Earth Planets Space 2016, 68, 13. [CrossRef]

36. Cetin, K.O.; Mylonakis, G.; Sextos, A.; Stewart, J. (Eds.) Seismological and Engineering Effects of the M 7.0 Samos Island (Aegean Sea) Earthquake. 2020. Available online: https://www.researchgate.net/publication/348277359_Seismological_and_ Engineering_Effects_of_the_M_70_Samos_Island_Aegean_Sea_Earthquake (accessed on 31 December 2020).

37. Aksoy, M.E. Post-event field observations in the İzmir-Sığacık village for the tsunami of the 30 October 2020 Samos (Greece) Mw 6.9 earthquake. Acta Geophys. 2021, 69, 1113-1125. [CrossRef]

38. Dogan, G.G.; Yalciner, A.C.; Yuksel, Y.; Ulutas, E.; Polat, O.; Guler, I.; Sahin, C.; Tarih, A.; Kanoglu, U. The 30 October 2020 Aegean Sea Tsunami: Post-Event Field Survey along Turkish Coast. Pure Appl. Geophys. 2021, 178, 785-812. [CrossRef]

39. Triantafyllou, I.; Gogou, M.; Mavroulis, S.; Lekkas, E.; Papadopoulos, G.A.; Thravalos, M. The Tsunami Caused by the 30 October 2020 Samos (Aegean Sea) Mw7.0 Earthquake: Hydrodynamic Features, Source Properties and Impact Assessment from Post-Event Field Survey and Video Records. J. Mar. Sci. Eng. 2021, 9, 68. [CrossRef]

40. U.S. Indian Ocean Tsunami Warning System Program (US IOTWS). Tsunami Warning Center Reference Guide Supported by the United States Agency for International Development and Partners; The United States Agency for International Development: Bangkok, Thailand, 2007; 311p.

41. Wang, Y.; Heidarzadeh, M.; Satake, K.; Mulia, E.I.; Yamada, M. A Tsunami Warning System Based on Offshore Bottom Pressure Gauges and Data Assimilation for Crete Island in the Eastern Mediterranean Basin. JGR Solid Earth 2020, 125, e2020JB020293. [CrossRef]

42. Necmioglu, F.; Turhan, D.S. Cambaz: A Comparison of Tsunami Warning through Decision Matrix, Pre-calculated Tsunami Scenario Database and Near-Real Time Tsunami Modelling: The Case of 30 October 2020 Mw6.9 Earthquake. In Proceedings of the 6th International Conference on Earthquake Engineering and Seismology (6th ICEES), Gebze, Turkey, 13-15 October 2021.

43. Selva, J.; Lorito, S.; Volpe, M.; Romano, F.; Tonini, R.; Perfetti, P.; Bernardi, F.; Taroni, M.; Scala, A.; Babeyko, A.; et al. Probabilistic tsunami forecasting for early warning. Nat. Commun. 2021, 12, 5677. [CrossRef] [PubMed]

44. Behrens, J. How to Handle Diverging TSP Warning Messages and Know about the Inherent Uncertainty. In Proceedings of the 14th Session of ICG/NEAMTWS, Lisbon, Portugal, 21-23 November 2017; Available online: http:/ /legacy.ioc-unesco.org/index php?option=com_oe\&task=viewDocumentRecord\&docID=20623 (accessed on 17 November 2021). 